\title{
Composite development and stratigraphy of the Onepoto maar lake sediment sequence (Auckland Volcanic Field, New Zealand)
}

\author{
Benjamin Läuchli ${ }^{1}$, Paul Christian Augustinus ${ }^{1}$, Leonie Peti ${ }^{1}$, and Jenni Louise Hopkins ${ }^{2}$ \\ ${ }^{1}$ School of Environment, The University of Auckland, Private Bag 920129, Auckland 1142, New Zealand \\ ${ }^{2}$ School of Geography, Environment and Earth Sciences, Victoria University of Wellington, P.O. Box 600, \\ Wellington 6140, New Zealand
}

Correspondence: Benjamin Läuchli (bluc030@aucklanduni.ac.nz)

Received: 28 October 2020 - Revised: 2 February 2021 - Accepted: 25 February 2021 - Published: 26 April 2021

\begin{abstract}
The accurate and precise reconstruction of Quaternary climate as well as the events that punctuate it is an important driver of the study of lake sediment archives. However, until recently lake sediment-based palaeoclimate reconstructions have largely concentrated on Northern Hemisphere lake sequences due to a scarcity of continuous and high-resolution lake sediment sequences from the Southern Hemisphere, especially from the southern mid-latitudes. In this context, the deep maar lakes of the Auckland Volcanic Field of northern New Zealand are significant as several contain continuous and well-laminated sediment sequences. Onepoto Basin potentially contains the longest temporal lake sediment record from the Auckland Volcanic Field (AVF), spanning from Marine Isotope Stage 6e (MIS 6e) to the early Holocene when lacustrine sedimentation was terminated by marine breach of the south-western crater tuff ring associated with post-glacial sea-level rise. The Onepoto record consists of two new, overlapping cores spanning ca. $73 \mathrm{~m}$ combined with archive material in a complete composite stratigraphy. Tephrochronology and ${ }^{14} \mathrm{C}$ dating provide the fundamental chronological framework for the core, with magnetic relative palaeo-intensity variability downcore, and meteoric ${ }^{10} \mathrm{Be}$ influx into the palaeolake to refine the chronology. The $\mu$-XRF (micro X-ray fluorescence) downcore variability for the entirety of the lake sediment sequence has been established with measurement of a range of proxies for climate currently underway. This work will produce the first continuous record of the last $200 \mathrm{kyr}$ of palaeoclimate from northern New Zealand to date.
\end{abstract}

\section{Introduction}

Deep-lake sediment archives allow for the development of a more comprehensive interpretation of past climatic and environmental evolution during the Quaternary than other continental climate archives, such as tree rings, peat bogs, and speleothems, and are often less prone to hiatuses than loess and fluvial deposits (Zolitschka and Enters, 2009). Sediments deposited in maar lakes often record regional climate signals due to the typically funnel-shaped crater structure of the maars and absence of major inlets and outlets (e.g., Marchetto et al., 2015), thereby minimising the flux of allochthonous sediment and other material into the lake basin (e.g., Brauer et al., 1999; Augustinus et al., 2011; Sandiford et al., 2003; Zolitschka et al., 2013). In contrast to the Northern Hemisphere where long, high-resolution late Quaternary terrestrial palaeoclimate archives are common and are well studied (e.g., the Eifel maar lakes in Germany; Sirocko et al., 2016), their New Zealand lake counterparts are few, often show poor resolution, and suffer from age controversies (e.g., Molloy et al., 2009; Hopkins et al., 2017). The Auckland maar lakes are crucial in the context of the Southern Hemisphere mid-latitudes as they contain archives representative of past south-western Pacific climate variability (Alloway et al., 2007). Furthermore, the location of Auckland is ideal for palaeoclimate studies, since it is located at the ecological boundary between the subtropical northern tip of New 
Zealand's North Island and the cooler central North Island as well as regions further south (Augustinus et al., 2012).

The maar lakes of the Auckland Volcanic Field (AVF) provide long, continuous, high-resolution (decadal to subdecadal), high-quality, laminated sediment records suitable for detailed examination of south-west Pacific palaeoclimate over the last $200 \mathrm{kyr}$ (Hopkins et al., 2017). Lacustrine sequences of comparable continuity and resolution are rarely encountered in the terrestrial mid-latitudes of the Southern Hemisphere and tend to cover shorter timescales. Furthermore, many distinct tephra layers from local basaltic activity (e.g., AVF) or rhyolitic and andesitic volcanic centres (VCs) further afield (e.g., Taupo Volcanic Zone (TVZ), Egmont/Taranaki Volcanic Centre $(\mathrm{TaVC})$ ) are preserved in these lacustrine archives (e.g., Shane and Hoverd, 2002; Molloy et al., 2009; Hopkins et al., 2015) and form isochronous markers for stratigraphic correlation to other maar lake sediment sequences (Molloy et al., 2009). In particular, a number of independently dated rhyolitic tephra allow for wellestablished age control for the past ca. $45 \mathrm{kyr}$ (Danišík et al., 2012). Pre-45 ka ages, of the rhyolitic, andesitic, and basaltic tephra, are often not well constrained, with their age estimates in many cases relying on interpolation from sedimentation rates between known-age TVZ-sourced rhyolitic tephra and correlation with the source volcanoes (Molloy et al., 2009; Lindsay et al., 2011; Peti and Augustinus, 2019). Furthermore, a range of proximal basaltic tephra (correlated to their source centres in the AVF) also provide additional age markers within the cores (Hopkins et al., 2017, 2020; Leonard et al., 2017).

Here we present a palaeolake sediment record from Onepoto maar that provides one of the few known opportunities for the identification of climatically forced environmental changes from the Southern Hemisphere mid-latitudes spanning much of the last ca. $200 \mathrm{kyr}$ (Hopkins et al., 2017). This report (1) details the approach used to construct a new robust composite stratigraphy for the Onepoto Basin lacustrine sequence and (2) highlights the potential of the Onepoto sediment sequence for investigation of how Southern Hemisphere and inter-hemispheric climate dynamics are linked at high-precision over the last two glacial cycles.

\section{Study site}

The maar studied here is located on modern-day Auckland's North Shore (Fig. 1d) and is the product of an explosive phreatomagmatic eruption that is proposed to have occurred not long after the formation of adjoining Lake Pupuke maar (mean age $193.2 \pm 2.8 \mathrm{ka}$ by ${ }^{40} \mathrm{Ar} /{ }^{39} \mathrm{Ar}$ dating; Leonard et al., 2017) based on morphostratigraphy (Hopkins et al., 2017). However, ${ }^{39} \mathrm{Ar}-{ }^{40} \mathrm{Ar}$ dating of basaltic lapilli attributed to the formative eruption of Onepoto maar indicates that the age of maar formation may be as old as $245 \pm 40 \mathrm{ka}$ (Sandiford et al., 2003; Shane and Sandiford, 2003). After the formative phreatomagmatic eruption, a freshwater lake developed in the maar fed by groundwater seepage and precipitation runoff from the crater rim. The maar lake persisted until an early Holocene sea-level rise breached the southwestern crater tuff ring, transforming the basin into an estuarine lagoon ca. 9.0 ka cal BP (Hägg and Augustinus, 2003; Hayward et al., 2008; Augustinus et al., 2011). The presentday Onepoto Basin (Fig. 1a) is occupied by a mixture of recreational parklands and wetlands whilst the surrounding tuff ring is densely covered with residential housing. The drill core presented in this study was recovered in 2018 from a central section of the crater in an area of profundal sedimentation based on previous exploratory drilling (Fig. 1a; Hägg and Augustinus, 2003; Augustinus et al., 2012).

\section{Methods}

\subsection{Coring}

A first scientific drilling campaign at Onepoto Basin in the years 2001/2002 produced a continuous lake sediment sequence to a depth of $\sim 60 \mathrm{~m}$ below the surface. This initial work produced a scientific drilling report (Hägg and Augustinus, 2003) and further publications (e.g., Shane and Hoverd, 2002; Shane and Sandiford, 2003; Augustinus et al., 2011, 2012). In 2011, another attempt to extract a complete sequence of lake sediment infill from the Onepoto maar crater was undertaken to refine the incomplete tephra record contained in Shane and Hoverd (2002) and Molloy et al. (2009). However, core disturbance and loss during extraction did not allow for the development of a complete sediment sequence. Consequently, a new drilling campaign occurred in October/November 2018 and recovered a minimally disturbed and overlapping sedimentary sequence via two adjacent cores that spanned the complete lacustrine sequence. The locations of all coring sites are given in Fig. 1a.

The drilling was undertaken using a Fraste XL 170 Duo mobile-drilling rig (rotary and sonic capable). Due to the soft nature of the sediments, the sonic function of the drilling rig was initially used to ensure the recovery of undisturbed lake sediment core segments. However, issues were encountered when drilling through the wet expansive muds/clays while operating the drill rig in the sonic mode. Better drilling progress was made (and a higher recovery rate of undisturbed core samples achieved) by simply operating the rig with its standard rotary function. The rig was set up near the centre of the Onepoto domain (Fig. 1a; degree-minute-second (DMS) coordinates: $36^{\circ} 48^{\prime} 30^{\prime \prime} \mathrm{S}, 174^{\circ} 45^{\prime} 1^{\prime \prime} \mathrm{E}$ ), corresponding to the depocentre of the maar crater defined from gravity and magnetic surveys (Nunns and Hochstein, 2019). A set of two overlapping cores (A and B cores) with $50 \mathrm{~cm}$ vertical and $4 \mathrm{~m}$ lateral offset between them was collected in 1.5 and $2 \mathrm{~m}$ long barrels, both with an internal diameter of $80 \mathrm{~mm}$. The filled core barrels were brought to the surface, and the sediments extruded into split PVC tubes. The upper $40 \mathrm{~m}$ 

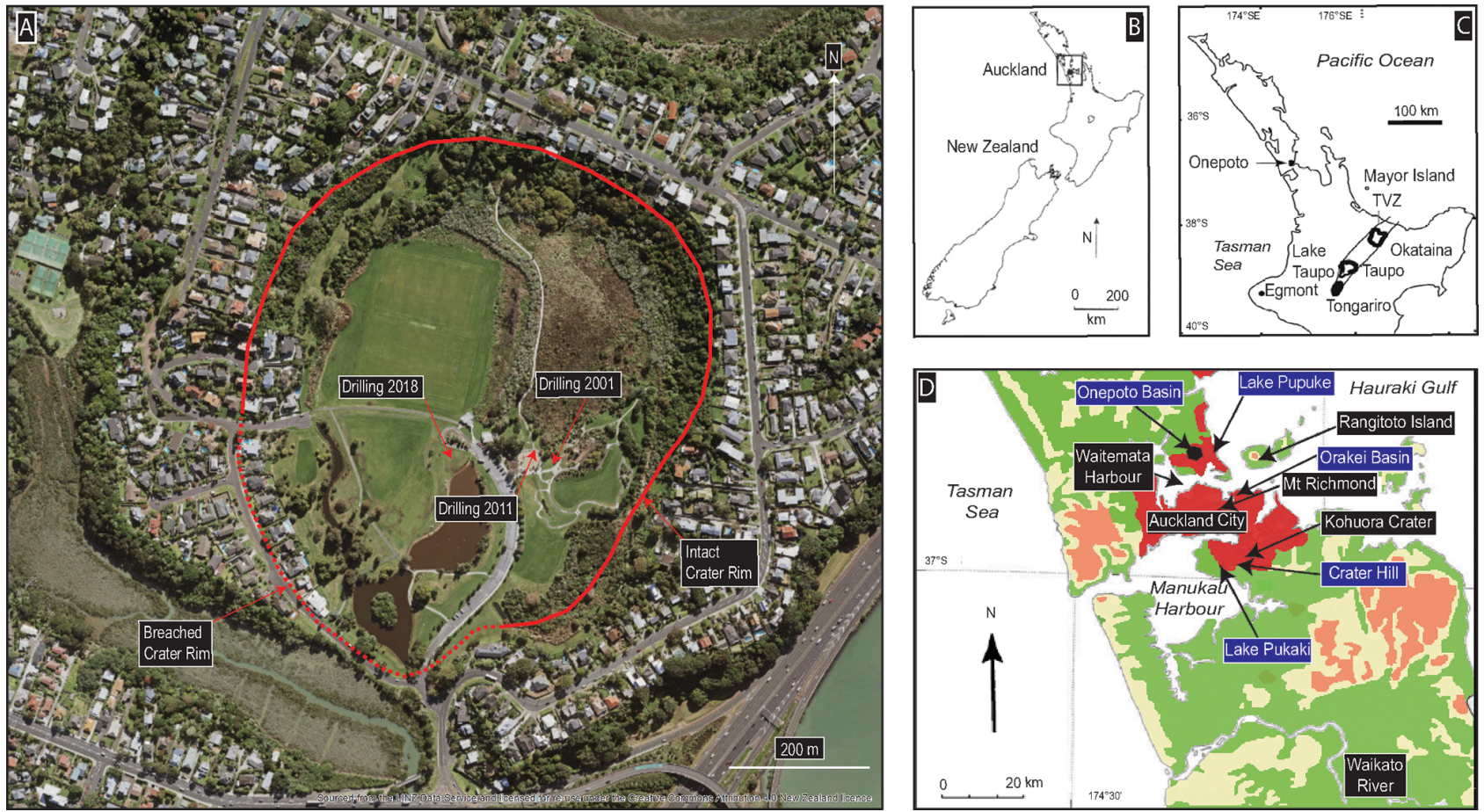

Figure 1. (a) Aerial photograph of the Onepoto domain study site with location of recent (2018; DMS coordinates: $36^{\circ} 48^{\prime} 30^{\prime \prime} \mathrm{S}$, $174^{\circ} 45^{\prime} 1^{\prime \prime} \mathrm{E}$; source from the LINZ Data Service and licensed for reuse under Creative Commons Attribution 4.0 New Zealand licence) and previous (2001-2002/2011) coring episodes (aerial footage sourced from the LINZ Data Service and licensed for reuse under the Creative Commons Attribute 4.0 New Zealand licence). (b) Overview of the North Island and South Island of New Zealand. (c) The North Island of New Zealand with its major volcanic centres. (d) The Auckland region with the location of significant maars that formed freshwater lakes in the AVF highlighted in blue.

of the overall sedimentary sequence consisted of estuarine mud of which $\sim 39 \mathrm{~m}$ was washed out before retrieving the underlying target laminated lake sediments $\sim 1 \mathrm{~m}$ above the marine-freshwater transition. Before the laminated lake sediment extraction was initiated, the boreholes were cased to prevent borehole closure during the deeper drilling. A maximum drilling depth of $73.2 \mathrm{~m}$ was achieved. However, the basalt lava encountered at the base of the core during the 2011 coring was not reached due to high water pressures at depth which prevented further drilling progress.

\subsection{Core description and visual facies identification}

The core sections were logged immediately after core splitting during preparation of the individual half core segments for X-ray-density and $\mu$-XRF (micro X-ray fluorescence) core scanning. All core surfaces were logged in a field-moist state (examples of representative core sections are given in Fig. 5) and described visually with regards to thickness and shape of laminations and sedimentary banding, sediment colour (Munsell Soil Color Chart 1992), approximated grain size (clay, silt, fine to coarse sand), bioturbation, macroscopic plant fragments, charcoal content, vivianite, volcanic ash layers (tephra), and visible disturbance of sedimentary struc- tures. Most lithostratigraphic units were identified following conventional methods and often exhibit distinct contacts between units. Individual units contain sediments of similar colour and character as well as the presence of laminations in some cases. Identified sub-units differentiate between intervals of smaller differences in colour, composition as well as the presence, quality, and thickness of laminations and bands.

\section{3 $\mu$-XRF core scanning and low-field volumetric magnetic susceptibility}

The sediment cores were scanned with an Itrax $\mu$-XRF core scanner (Cox Analytical Systems, Sweden) at the School of Environment, The University of Auckland, New Zealand. The approach of $\mu$-XRF core scanning involves very little sample preparation and is nondestructive (Croudace et al., 2006; Croudace and Rothwell, 2015). To establish a downcore record of elemental variability, measurements were taken at $1 \mathrm{~mm}$ increments with $10 \mathrm{~s}$ exposure time per measurement point. Both Mo (at $30 \mathrm{kV}, 55 \mathrm{~mA}$ ) and $\mathrm{Cr}$ tubes (at $60 \mathrm{kV}, 30 \mathrm{~mA}$ ) were used as X-ray sources to achieve an excitation of the full range of detectable elements (Mg (by Cr tube) and $\mathrm{Al}-\mathrm{U}$ ) with both increased detection precision for heavier (Mo tube $=Z \geq 26$ ) as well as lighter elements 
(Cr tube $=Z \leq 26$; Jarvis et al., 2015; St.-Onge et al., 2007). Additionally, high-resolution optical images $(47 \mu \mathrm{m})$ and radiographic images (at $60 \mathrm{kV}, 50 \mathrm{~mA}$; at $1 \mathrm{~mm}$ ) were also produced during the scanning process. Supplementary highresolution radiographic images $(0.2 \mathrm{~mm}$ resolution) were obtained with the aim to reveal sedimentary layers and grains, fine tephra beds and to identify pieces of wood/bark or seeds for ${ }^{14} \mathrm{C}$ dating (Croudace et al., 2006; Francus et al., 2009; Croudace and Rothwell, 2015). Low-field volumetric magnetic susceptibility was recorded for all cores with a handheld Bartington MS2 with a MS2e surface scanning sensor system at $5 \mathrm{~mm}$ increments and the range scale set to 0.1 . Core sections from the 2011 campaign were also scanned with the Itrax $\mu$-XRF elemental core scanner using a Mo tube (at $30 \mathrm{kV}, 55 \mathrm{~mA}$ ) to facilitate correlation with the new 2018 sequence. XRF data were acquired by following the same method as for the 2018 cores.

\subsection{Tephra identification based on geochemical fingerprinting}

Eighty five out of the identified 89 tephra horizons were sampled for geochemical fingerprinting from the newly obtained sediment cores and sieved (mesh size $=36 \mu \mathrm{m}$ ) under distilled water at The University of Auckland (New Zealand). Further sample preparation and the analysis itself on an electron micro-probe analyser (EMPA) were conducted at Victoria University of Wellington (New Zealand). Each sample was poured into a hole of a mount and then filled with epoxy resin. Afterwards, the pugs were thoroughly shaken to remove air bubbles before being left to cure. Once fully solidified, the bottom side of the samples was polished stepwise to expose fresh glass shard surfaces. The quality of the polished surface and its cleanliness were checked under the microscope. In a final step the individual pugs were carbon coated. The geochemical analyses were run using a JEOL JXA 8230 Superprobe using the following instrument settings: $15 \mathrm{kV}$ acceleration voltage and $\sim 8 \mathrm{nA}$ beam current for glass analysis. Matrix-matched standard A99 basaltic glass was used as a bracketing standard, while for rhyolitic and intermediate glass samples VG-568 was used. To avoid instrument drift, standards were run every 20 samples.

\subsection{Radiocarbon dating}

The ${ }^{14} \mathrm{C}$ age determinations were carried out on seven bulk sediment samples. Preparation for the analysis involved physical pre-treatment (sample drying, gentle break up, transferred to a centrifuge tube and weighed on a balance) at The University of Auckland (New Zealand) and several steps of standard chemical pre-treatment of organic samples from sediments (first $\mathrm{HCl}$ acid washing, $\mathrm{NaOH}$ alkali treatment and final $\mathrm{HCl}$ acid treatment) at ANSTO (Australian Nuclear Science and Technology Organisation, Sydney, Australia). The analyses were undertaken at the ANTARES AMS (accelerator mass spectrometry) facility at ANSTO following the procedure outlined in Fink et al. (2004). Rbacon (version 2.4.3; Blaauw and Christen, 2011) in $\mathrm{R}$ (version 1.3.1073; R Core Team, 2020) was used to calibrate AMS ${ }^{14} \mathrm{C}$ ages using the latest SHCal20 calibration (Hogg et al., 2020) and for construction of the preliminary age model.

\subsection{Composite stratigraphy development and core chronology}

The 2018 A and B core segments were correlated using guidelines outlined in Peti and Augustinus (2019). Initial core section matching was guided by the vertical offset (here $0.5 \mathrm{~m}$ ) between cores A and B, with the marine-freshwater transition $(\mathrm{M} / \mathrm{F})$ used as a top-of-core reference horizon to enable comparison to previous work at Onepoto Basin (e.g., Augustinus et al., 2011, 2012). Core matching was mainly achieved using the following:

1. Geochemical fingerprinting and correlation of tephra layers,

2. Comparison of high-resolution optical and X-ray density images,

3. Correlation of magnetic susceptibility and $\mu$-XRF data (Ti normalised against inc+coh; with a Mo tube as Xray source).

Figure 2 provides a depiction of core section alignment using high-resolution optical images, Itrax $\mu$-XRF and lowfield volumetric magnetic susceptibility data.

Due to the proximity of the A and B core drill sites $(\sim 4 \mathrm{~m})$, marker layers, such as tephra layers, mass movement deposits, distinct segments with well-laminated sediments, and features representative for individual lithostratigraphic units, were generally encountered in the overlapping core sections. However, a tendency for an increased variability in thickness of sedimentary features between the A and B cores was noted at depths $>46 \mathrm{~m}$. This is in accordance with previous studies which have found that even in close-proximity cores from deep maar lake basin environments, corresponding sedimentary features can differ in thickness between adjacent cores (e.g., Peti and Augustinus, 2019; Poth and Negendank, 1993; Williams et al., 1993). Core segments expanded significantly after extraction and removal of the sediment overburden, especially where the segments were dominated by soft, organic-rich mud. To correct for this, the specific core segments were compressed by a factor equivalent to the amount of expansion (range of expansion in certain cases up to $30-50 \mathrm{~cm}$ ), with the drill rod length ( 1.5 or $2 \mathrm{~m}$ ) being the measure. Table S1 in the Supplement provides an overview on the amount of expansion and adjusted depths for the composite record build. The relative positions of related data points (e.g., loss-on-ignition, sediment carbon/nitrogen and stable isotope content, biomarker, and pollen sampling) have been recalculated accordingly. 


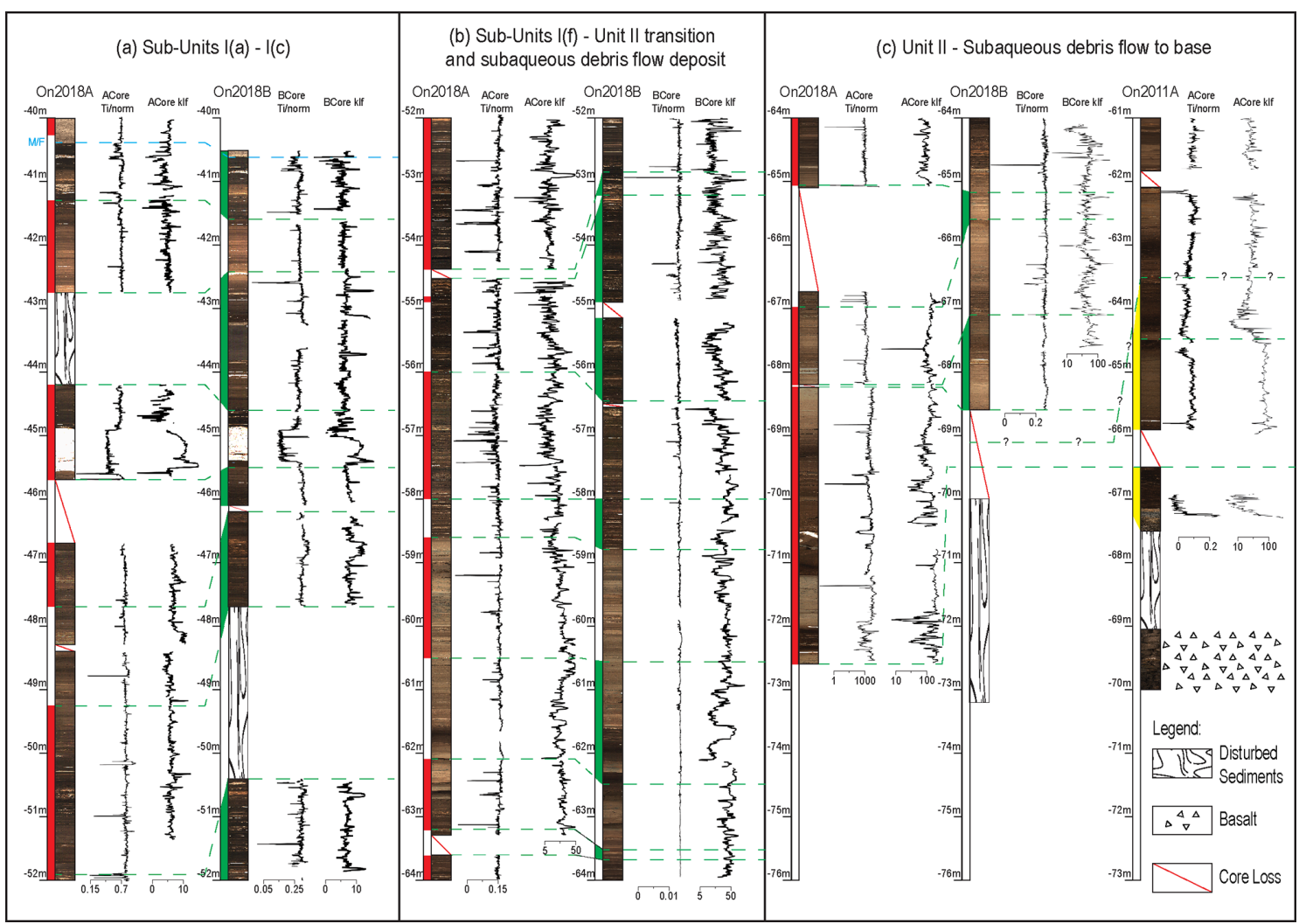

Figure 2. Schematic depiction of core section alignment using high-resolution optical images, Itrax $\mu$-XRF Ti/norm., and low-field volumetric magnetic susceptibility (klf) data (dimensionless Si units $\times 10^{-5}$ ). Red highlights the 2018 core A (ACore) sample chosen for composite; green highlights the 2018 core B (BCore) sample chosen for composite; and yellow highlights the 2011 core A archive material chosen for composite. Symbol * represents normalisation with inc+coh to correct for variability in water and organic matter content, grain size, and ageing of the X-ray tube (Löwemark et al., 2011; Kylander et al., 2012).

A complete composite record that spans the entire lacustrine sequence was established by linking the A and B cores from the 2018 drilling with archive core material from the 2011 coring campaign. An event-corrected depth scale (ECD) was established by removal of all identified instantaneous event deposits (89 primary tephra and 211 mass movement deposits: total thickness of tephra and mass movement layers of $\sim 6.90 \mathrm{~m}$ ). Mass influx material could usually be identified visually or using the radiographic images. If not already visually distinct, tephra layers were identified through a combination of magnetic susceptibility measurements (e.g., increased $\mathrm{Fe}$ content (magnetite) in basaltic tephra), $\mu$-XRF core scanning ( $\mathrm{Si}$ and $\mathrm{Sr}$ were found to be the most reliable elements for rhyolitic tephra layer identification) and X-ray density images.

\section{Results and discussion}

\subsection{Lithostratigraphic units}

The laminated lake sediments are overlain by $\sim 40 \mathrm{~m}$ of estuarine muds (see Figs. 3 and 4). A general lithostratigraphic model for the laminated lacustrine sequence was produced by Hägg and Augustinus (2003) from a single and incomplete core retrieved ca. $200 \mathrm{~m}$ east of the crater centre (Fig. 1). In general, the existing lithostratigraphic model could be transferred to the 2018 sequence, with individual unit boundaries usually encountered at similar depths. Detailed descriptions of the individual units are provided in Table 1 and are depicted in Fig. 3. The sequence was divided into two main units and six individual sub-units for Unit I. However, the underlying Unit II could not easily be subdivided into individual sub-units during logging due to the lack of clear transitions from one facies type to the next and frequent disruption of the sequence by mass-wasting deposits. Furthermore, Unit II differs from Unit I in containing many mass movement deposits (centimetre- to metre-scale thickness) and inwashed organic detritus that was only found sporadically in sub-units I(e) and I(f). A sharp contact that would mark the transition from Unit I to Unit II could not be identified. In our model an approximated boundary was defined based on the onset of increased presence of coarse sand to gravel-rich layers. The main difference between the 2001/02 and 2018 records lies in facies Unit II being $10.45 \mathrm{~m}$ thicker in the 
2018 core collected at the centre of the maar lake. This indicates that the bulk of mass movement material transported into the basin accumulated in the depocentre of the basin. A cross-section of the crater established based on the results of all three coring campaigns confirms a nearly bowl-shaped geometry (Fig. 4) for the crater as proposed by Nunns and Hochstein (2019). However, a reported primary estimate of $63 \mathrm{~m}$ for the depth of crater infill (Nunns and Hochstein, 2019) is not supported by the coring results produced from the recent 2011 and 2018 drill holes from which we deduce an overall thickness of $73.2 \mathrm{~m}$. For the newly established composite record presented here, we rule out doubling up of core segments as a reason for the significant difference in length between the two cores while building the new composite sedimentary sequence since the preserved sedimentary features, when combined with the $\mu$-XRF and magnetic susceptibility data, allow for straightforward core correlation. Furthermore, a comparison of the overall thickness of the lacustrine sequence as recorded in the 2011 and the new 2018 cores shows a $\sim 5 \mathrm{~m}$ difference (2011 core of $\sim 31 \mathrm{~m}$ vs. newly established composite record of $\sim 36 \mathrm{~m}$ ), which could be related to technical issues and core loss during the 2011 drilling campaign.

\subsection{Tephra identification}

Eleven rhyolitic (Rotoma, Waiohau, Rotorua, Rerewhakaaitu, Okareka, Kawakawa/Oruanui, Okaia, Hauparu, Maketu, Tahuna, and Rotoehu) and one andesitic tephra (Eg4) were identified based on geochemical fingerprinting. The identification of these tephra layers (and their correlation to the formative eruptive events), is supported by the geochemical composition of the glass shards contained in the individual tephra as well as their relative stratigraphic position to the tephrochronological frameworks in Shane and Hoverd (2002) and Molloy et al. (2009). Reported average deposit thicknesses were also often referred to for additional supportive evidence. Major-element oxide bivariate plots of reference tephra data and rhyolitic tephra glass shards presented here are depicted in Fig. 6. This has allowed for a direct transfer of published ages onto the Onepoto lake sediment sequence. The corresponding glass analysis data are provided in Table S2 of the Supplement. Figure 7a to c depict how well the EMPA geochemistry for the probed rhyolitic tephra overlap with the glass-based reference data available from Molloy (2008) and reflect the expected geochemistry of the eruptive centres from which the individual tephra beds originate, analogues to the descriptions in Molloy et al. (2009). Furthermore, EMPA geochemistry for Eg4 is plotted in Fig. 7d-f. The stratigraphic position and geochemical composition of the targeted bed in the new Onepoto record assigned to $\mathrm{Eg} 4$ by us matches most with the corresponding Eg4 bed assigned by Molloy et al. (2009). A comparison to the next stratigraphically closest Egmont/Taranaki sourced tephra, Eg3, resulted in a non-conclusive overlap and a less robust stratigraphic cross-correlation. Additionally, three AVF-sourced basaltic deposits (AVF B, AVF C and AVF D) have been assigned based on stratigraphic position relative to the established AVF tephrochronology (Hopkins et al., 2015; Molloy et al., 2009), whereas the vertical position of AVF 1 recently calculated to $90.435 \pm 1.555 \mathrm{ka} \mathrm{cal} \mathrm{BP}$ (Peti et al., 2021) to date could not be reliably identified. The latter, however, is subject of further investigation by applying klf and $\mu$-XRF downcore variability data trends matching from relevant sections of the Onepoto and the Orakei record. All assigned eruptive events with ages are summarised in Table 2.

\subsection{Radiocarbon dating}

All seven radiocarbon ages obtained from the Onepoto core on bulk organic matter are summarised in Table 3. Terrestrial macro-organic remains, which are commonly more preferable for ${ }^{14} \mathrm{C}$ dating, were not available from the $<50 \mathrm{ka}$ part of the record. The study therefore had to resort to bulk organic matter for this approach. As influx of old organics from eroded soils, mobilised from the crater rim, is limited for the later phase of the lake's existence, we expect the results of the AMS radiocarbon age dating from bulk organic matter to be adequate. Furthermore, due to the lack of carbonates in the catchment, any distortion due to a hard water effect is unlikely.

\subsection{Age-depth model based on the tephrochronology and radiocarbon ages}

An updated age model for the Onepoto lake sequence (Fig. 7) has been established that relies on the identification of 11 known-age rhyolitic tephra beds (ca. 9-ca. $50 \mathrm{ka}$ ) with sufficiently distinct geochemistry and AMS radiocarbon ages obtained from the core on bulk organic matter. The presence of the 11 rhyolitic tephra deposits with reliable ages in tight succession help to constrain the resulting ${ }^{14} \mathrm{C}$ ages. For the $>50$ ka part of the record, the andesitic "Eg4" tephra $(77.165 \pm 1.5 \mathrm{ka}$; Peti et al., 2021) allows for correlation with the newly refined Orakei maar crater lake sediment record (Peti and Augustinus, 2019; Peti et al., 2020). Basaltic ejecta dating back to the early stages of Onepoto maar lake formation (AVF D) are used as age tie points (AVF B, $146.9 \pm 2.8 \mathrm{ka}$; Hopkins et al., 2017; Leonard et al., 2017; AVF C, estimated age $181 \pm 0.6 \mathrm{ka}$; Hopkins et al., 2017). The age of maar formation is currently proposed to have occurred $>150 \mathrm{ka}$ and $<193 \mathrm{ka}$ (Hopkins et al., 2017; Leonard et al., 2017) but may be as old as $245 \pm 40 \mathrm{ka}$ based on ${ }^{39} \mathrm{Ar}-{ }^{40} \mathrm{Ar}$ dating of basaltic lapilli attributed to the formative eruption (Sandiford et al., 2003; Shane and Sandiford, 2003). Based on the available evidence, we consider the latter age to be problematic and have thus only included the former in our age model. For the younger age, we use the established mean age of formation of adjacent Lake Pupuke 


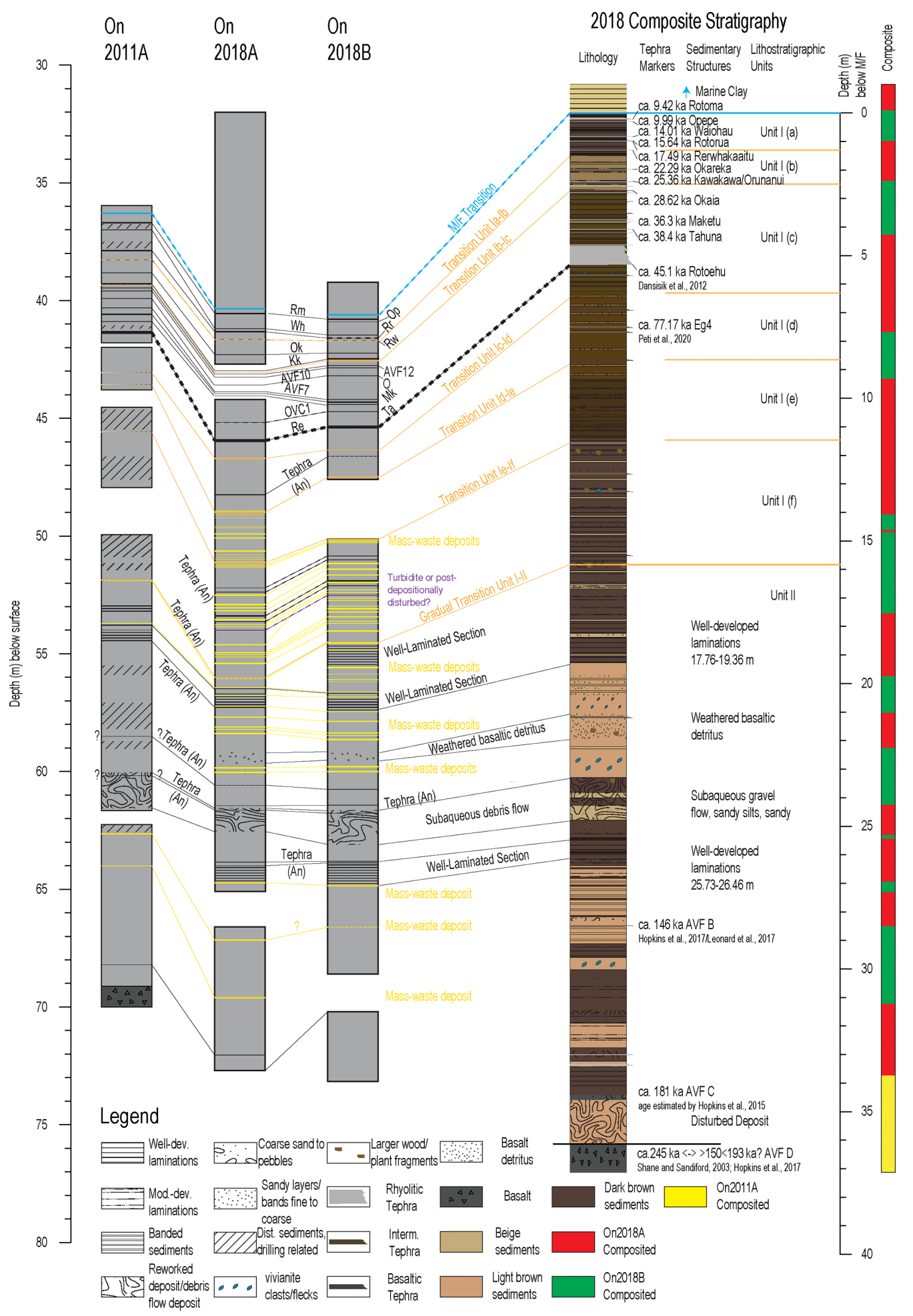

Figure 3. Onepoto maar palaeolake composite stratigraphy, lithological descriptions, and tephra marker layers. Tephra abbreviations: $\mathrm{Rm}=$ Rotoma; $\mathrm{Wh}=$ Waiohau; $\mathrm{Rr}=$ Rotorua; $\mathrm{Rw}=$ Rerewhakaaitu; Ok = Okareka; Kk= Kawkawa/Oruanui; Op = Opepe; AVF 12, AVF 10, AVF 7 = basaltic tephra, AVF sourced (Molloy et al., 2009); O= Okaia; Mk = Maketu; Ta = Tahuna; OVC1 = rhyolitic tephra, Okataina Volcanic Centre sourced (Molloy et al., 2009); Re = Rotoehu; An = andesitic tephra. Detailed lithostratigraphic descriptions are provided in Table S1 of the Supplement. 


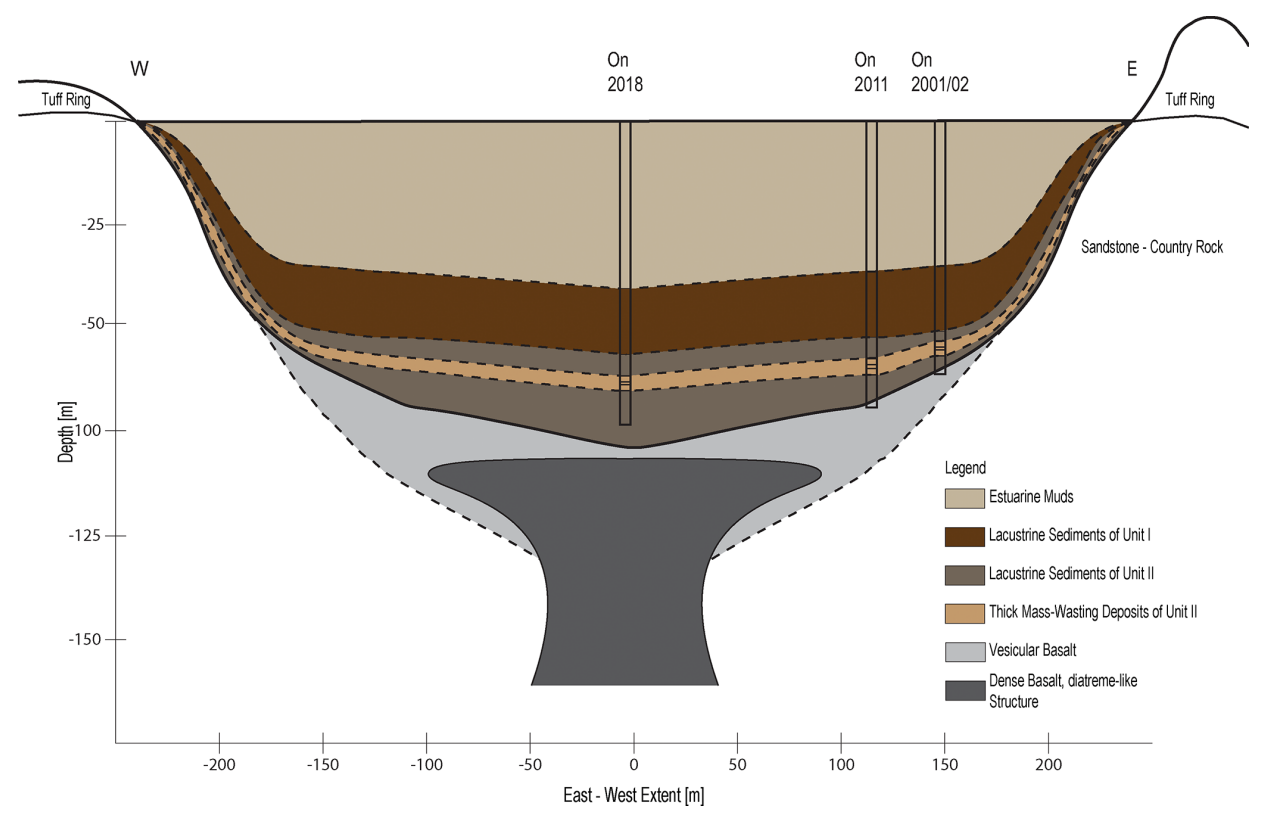

Figure 4. Cross-section of the crater and its infill. Extent and position of diatreme-like structure under the crater and vesicular basalt at depth guided by descriptions in Nunns and Hochstein (2019) as well as drill core findings (On2011, On2001/02) for the latter. Thickness and lateral extent of major lithostratigraphic units taken or estimate based on drill core findings (On2018, On2011, and On2001/02).

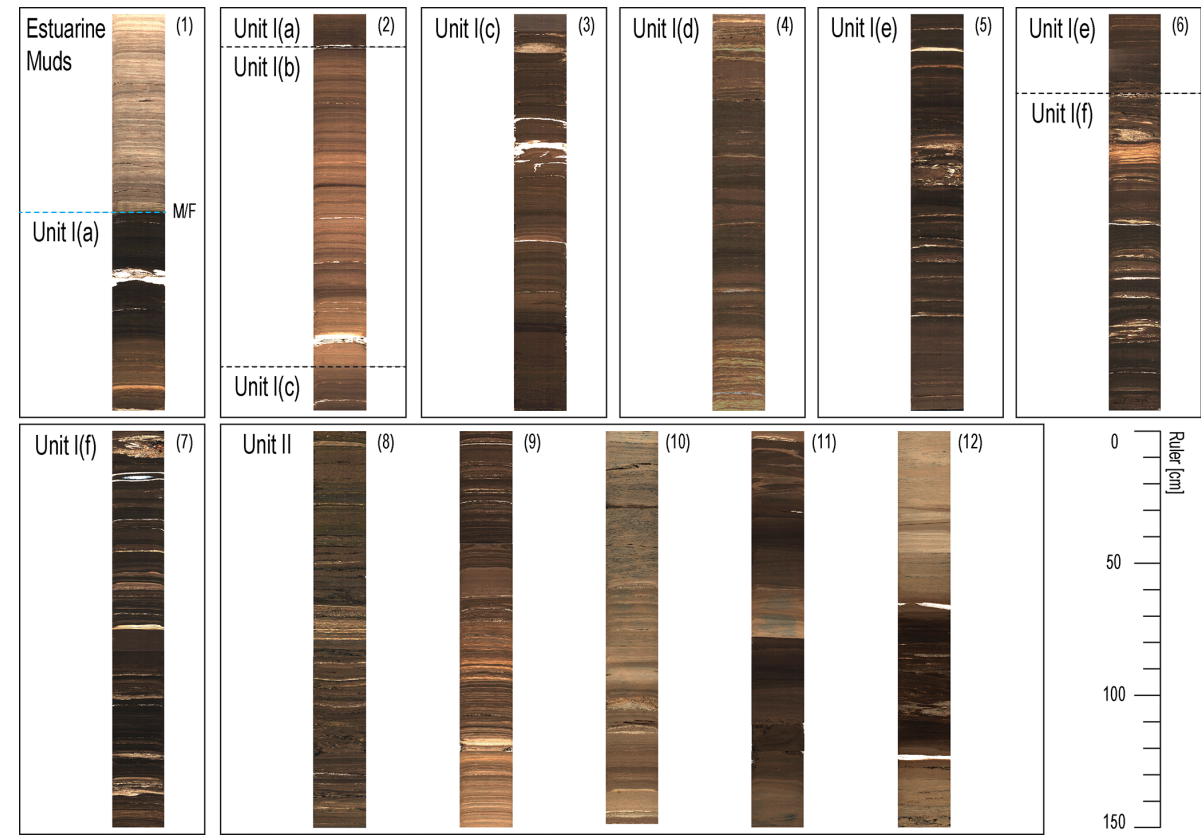

Figure 5. High-resolution core section images representative of the main facies units (Unit I and Unit II) as well as the six sub-units of Unit I (I(a) to I(e)). The depicted core images are ca. $1.5 \mathrm{~m}$ long. An = andesitic tephra, B = basaltic tephra, Rh= rhyolitic tephra. (1) Transition from estuarine muds to Unit I(a); (2) transition from Unit I(a) over Unit I(b) to Unit I(c); (3) sediments of Unit I(c); (4) sediments of Unit $\mathrm{I}(\mathrm{d})$; (5) sediments of Unit I(e) with moderately developed laminations, occasional lighter and darker coloured bands; (6) transition from Unit I(e) to Unit (f) with coarser grained mass-waste deposits and their finer, orange-coloured gritty bands. (7) Sediments of Unit I(f) with coarse-grained (centimetre-scale) mass-waste deposits, fine, orange-coloured gritty bands, and centimetre-scale vivianite nodule bracketed by andesitic tephra (see top of core section); (8) well-developed laminations of Unit II; (9) well-developed laminations with decreasing quality downcore; (10) weathered basaltic detritus in Unit II; (11) subaqueous debris flow deposit Unit II; and (12) rhyolitic tephra ca. 2 m above the core base. 

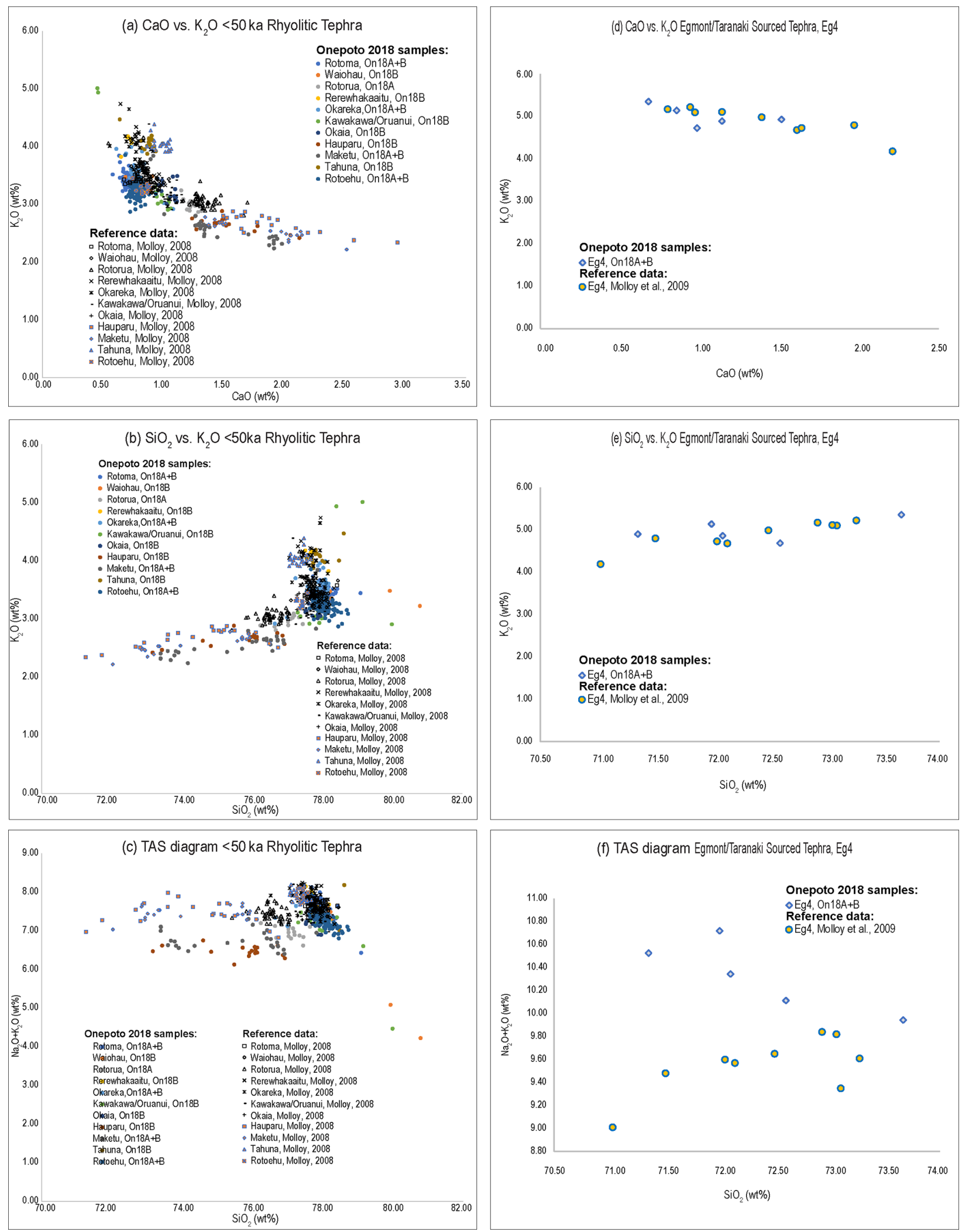

Figure 6. Glass shard major-element oxide bivariate plots of reference glass tephra data (taken from Molloy, 2008) and Onepoto (2018 drilling) samples. 
Table 1. Description of the lithostratigraphic units for the 2018 Onepoto composite record based on the naming convention defined by Hägg and Augustinus, 2003. ECD represents event-corrected depth.

\begin{tabular}{|c|c|c|c|}
\hline Lithostratigraphic unit & $\begin{array}{l}\text { Depths below } \\
\text { marine-freshwater } \\
\text { transition }(\mathrm{M} / \mathrm{F})[\mathrm{m}]\end{array}$ & $\mathrm{ECD}[\mathrm{m}]$ & Description \\
\hline Unit I - Sub-Unit I(a) & $0.0-1.5$ & $0.0-$ ca. 1.2 & $\begin{array}{l}\text { Silts deposited prior to marine breach. Mainly } \\
\text { dark brown to black, with well-developed lam- } \\
\text { inations (sub-millimetre) and lighter-coloured } \\
\text { centimetre-scale bands. A lighter-brown to } \\
\text { greyish-brown section is present from } 0.42- \\
0.69 \mathrm{~m} \mathrm{M} / \mathrm{F} \text {. }\end{array}$ \\
\hline Unit I - Sub-Unit I(b) & $1.5-2.7$ & ca. $1.2-2.5$ & $\begin{array}{l}\text { Silts of dark grey to grey, brown colour } \\
\text { with moderately developed laminations (sub- } \\
\text { millimetre thickness) and bands ( } 1-5 \mathrm{~mm} \text { thick- } \\
\text { ness). }\end{array}$ \\
\hline Unit I - Sub-Unit I(c) & $2.70-6.24$ & ca. $2.5-5.4$ & $\begin{array}{l}\text { Silty clays, dark brown faint bands }(1-5 \mathrm{~mm} \\
\text { thickness), well-developed laminations present } \\
\text { (sub-millimetre thickness). }\end{array}$ \\
\hline Unit I - Sub-Unit I(d) & $6.24-9.34$ & ca. $5.4-8.16$ & $\begin{array}{l}\text { Silty clays of light brown to light greyish-brown } \\
\text { colour with little to no laminations present but } \\
\text { gritty fine sand and lighter and darker bands } \\
\text { (centimetre scale). }\end{array}$ \\
\hline Unit I - Sub-Unit I(e) & $9.34-11.38$ & ca. $8.39-10.18$ & $\begin{array}{l}\text { Clays, dark brown to black, with moderately de- } \\
\text { veloped laminations (sub-millimetre thickness) } \\
\text { to increasingly well-developed downcore and } \\
\text { lighter and darker bands ( } 10-20 \mathrm{~mm} \text { thick) and } \\
\text { occasional } \leq 10 \mathrm{~mm} \text { thick light brown fine sand } \\
\text { bands. }\end{array}$ \\
\hline Unit I - Sub-Unit I(f) & $11.38-15.72$ & ca. $10.18-13.38$ & $\begin{array}{l}\text { Very dark brown to black, also abundant light } \\
\text { brown to olive coloured and greyish-brown } \\
\text { ( } 10-20 \mathrm{~mm} \text { thick) bands. Fine to medium sand } \\
\text { layers are common and well-developed lami- } \\
\text { nations are present (sub-millimetre thickness). } \\
\text { Increased plant fragment content and vivianite } \\
\text { flecks. }\end{array}$ \\
\hline Unit II & $15.72-36.12$ & ca. $13.38-29.47$ & $\begin{array}{l}\text { Silty clays and silts with colours ranging from } \\
\text { dark greyish-brown to olive grey and lam- } \\
\text { inations generally poorly to medium well- } \\
\text { developed as well as a high content of coarse } \\
\text { sand to gravel-rich layers. However, also sec- } \\
\text { tions with well-developed laminations present } \\
(17.76-19.36 \mathrm{~m}, 25.73-26.46 \mathrm{~m} \mathrm{M} / \mathrm{F}) \text {. }\end{array}$ \\
\hline
\end{tabular}

maar (193 $\pm 2.8 \mathrm{ka}$; Leonard et al., 2017) as minimum age of the suggested $>150 \mathrm{ka}$ and $<193 \mathrm{ka}$ (Hopkins et al., 2017; Leonard et al., 2017). Tephra and AMS ${ }^{14} \mathrm{C}$ ages are given in Tables 2 and 3. Rbacon (version 2.5.1; Blaauw and Christen, 2011) in R (version 1.3.1103; R Core Team, 2020) was used to calibrate AMS ${ }^{14} \mathrm{C}$ ages using the latest SHCal20 calibration (Hogg et al., 2020) and to construct the age model, using a prior accumulation rate of $100 \mathrm{yr} / \mathrm{cm}$ (Fig. 7a) and $50 \mathrm{yr} / \mathrm{cm}$ (Fig. 7b) based on a ballpark estimate provided by Rbacon. Prior accumulation shape, memory strength and memory mean follow the suggestions provided by the Rbacon age model presented in Blaauw and Christen (2011). Revised tephra ages provided by Lowe et al. (2013) and Peti et al. (2021) permit correction of sedimentation rates and inferred ages for non-numerically dated tephra (largely Egmont/Taranaki VC-sourced andesitic tephra) as previously reported by Molloy et al. (2009) and Augustinus et al. (2011). Furthermore, we present a new sedimentation rate model for 
Table 2. Rhyolitic and andesitic tephra marker beds and basaltic deposits preserved in the Onepoto lake sediment record with assigned ages. ECD represents event-corrected depth.

\begin{tabular}{|c|c|c|c|c|c|c|c|}
\hline Tephra ID & Material & $\begin{array}{r}\text { Thickness } \\
{[\mathrm{mm}]}\end{array}$ & $\begin{array}{r}\text { Age } \\
{[\text { cal BP }]}\end{array}$ & $\begin{array}{r}\text { Error } \\
( \pm 2 \sigma)\end{array}$ & $\begin{array}{l}\text { Depth below } \\
\text { marine-freshwater } \\
\text { transition }(\mathrm{M} / \mathrm{F})[\mathrm{m}]\end{array}$ & $\begin{array}{r}\text { ECD } \\
\text { depth }[\mathrm{m}]\end{array}$ & Age taken from \\
\hline Rotoma & Rhyolite & 50 & 9423 & 120 & 0.23 & 0.23 & Lowe et al. (2013) \\
\hline Opepe & Rhyolite & 5 & 9991 & 160 & 0.32 & 0.27 & Lowe et al. (2013) \\
\hline Waiohau & Rhyolite & 1 & 14009 & 155 & 0.83 & 0.78 & Lowe et al. (2013) \\
\hline Rotorua & Rhyolite & 35 & 15635 & 412 & 0.98 & 0.89 & Lowe et al. (2013) \\
\hline Rerewhakaaitu & Rhyolite & 2 & 17496 & 462 & 1.32 & 1.23 & Lowe et al. (2013) \\
\hline Okareka & Rhyolite & 3 & 23525 & $1390^{\mathrm{a}}-210$ & 1.96 & 1.89 & $\begin{array}{l}\text { Original age from Mol- } \\
\text { loy et al. (2009); calibrated } \\
\text { with SHCal20 (Hogg et al., } \\
\text { 2020); Peti et al., 2020, } \\
2021 \text { ) }\end{array}$ \\
\hline Kawakawa/Oruanui & Rhyolite & 30 & 25360 & 160 & 2.43 & 2.3 & Vandergoes et al. (2013) \\
\hline Okaia & Rhyolite & 5 & 28621 & 1428 & 2.81 & 2.66 & Lowe et al. (2013) \\
\hline Maketu & Rhyolite & 20 & 36100 & 900 & 3.83 & 3.61 & Danišík et al. (2020) \\
\hline Tahuna & Rhyolite & 1 & 38400 & 1700 & 4.1 & 3.88 & Danišík et al. (2020) \\
\hline Rotoehu & Rhyolite & 720 & 45100 & 3300 & 5.34 & 4.51 & Danišík et al. (2012) \\
\hline $\mathrm{Eg} 4$ & Andesite & 5 & 77165 & $1400-1455^{\mathrm{b}}$ & 7.63 & 6.76 & Peti et al. (2021) \\
\hline AVF B & Basalt & 20 & 146900 & 2800 & 28.07 & 22.26 & Leonard et al. (2017) \\
\hline AVF C & Basalt & 360 & 181000 & 600 & 34.82 & 27.91 & $\begin{array}{l}\text { Inferred age in Hopkins et } \\
\text { al. (2017) }\end{array}$ \\
\hline AVF D & Basalt & Bedrock & $>150000<193000$ & 2800 & 36.12 & 29.47 & $\begin{array}{l}\text { Hopkins et al. (2017); } \\
\text { Leonard et al. (2017) }\end{array}$ \\
\hline $\begin{array}{l}\text { AVF D (proble- } \\
\text { matic alternative } \\
\text { age) }\end{array}$ & Basalt & Bedrock & 245000 & 40000 & 36.12 & & $\begin{array}{l}\text { Shane and Sandiford } \\
(2003)\end{array}$ \\
\hline
\end{tabular}

a As Bacon does not allow asymmetrical errors by default for non-radiocarbon dates, a $2 \sigma$ error of 1390 was used

b As Bacon does not allow asymmetrical errors by default for non-radiocarbon dates, a $2 \sigma$ error of 1455 was used.

Table 3. AMS radiocarbon ages from the Onepoto maar lake sediment record. Ages calibrated against SHCal20 (Hogg et al., 2020) in OxCal version 4.4; (Bronk Ramsey, 2009), with reserved data repository https://doi.org/10.6084/m9.figshare.13683874.

\begin{tabular}{lcrrrrrrr}
\hline Sample ID & Sample type & $\begin{array}{r}\text { Conventional } \\
\text { AMS }{ }^{14} \mathrm{C} \text { age }\end{array}$ & $\begin{array}{r}\delta^{13} \mathrm{C} \\
\text { per mil }\end{array}$ & $\begin{array}{r}\text { Error } \\
( \pm 1 \sigma)\end{array}$ & $\begin{array}{r}\text { Age } \\
{[\text { cal BP] }}\end{array}$ & $\begin{array}{r}\text { Error } \\
( \pm 2 \sigma)\end{array}$ & $\begin{array}{r}\text { Depth below } \\
\text { M/F }[\mathrm{m}]\end{array}$ & $\begin{array}{r}\text { ECD } \\
{[\mathrm{m}]}\end{array}$ \\
\hline OZZ288 & Bulk sediment & 10340 & -28.2 & \pm 0.1 & 12199 & 151 & 0.56 & 0.51 \\
OZZ273 & Bulk sediment & 10860 & -29.5 & \pm 0.1 & 12785 & 30 & 0.64 & 0.59 \\
OZZ274 & Bulk sediment & 13890 & -28.9 & \pm 0.2 & 16880 & 92 & 1.08 & 0.99 \\
OZZ278 & Bulk sediment & 17200 & -20.3 & \pm 0.1 & 20752 & 86 & 1.71 & 1.62 \\
OZZ280 & Bulk sediment & 20050 & -22.2 & \pm 0.1 & 24049 & 98 & 2.15 & 2.05 \\
OZZ281 & Bulk sediment & 30430 & -28.2 & \pm 0.1 & 34844 & 200 & 2.32 & 3.45 \\
OZZ283 & Bulk sediment & 39710 & -27.9 & \pm 0.1 & 43056 & 320 & 4.32 & 4.10 \\
\hline
\end{tabular}

Onepoto applicable prior to the deposition of the Rotoehu tephra (45.1 $\pm 3.3 \mathrm{ka}$; Danišík et al., 2012) and post-AVF C eruption age.

Calculated sedimentation rates seem to support a time of eruption younger than $193 \mathrm{ka}$. However, the data density for the pre-50 ka record is low, which emphasises the need for further age markers in this part of the sequence. We anticipate that the reconstruction of meteoric ${ }^{10} \mathrm{Be}$ flux into the lake basin proposed by us and U/Th dating on a large $(4 \times 1 \mathrm{~cm})$ vivianite nodule (Sub-Unit I(f), ca. $13.35 \mathrm{~m}$ below M/F transition; estimated age ca. $93 \mathrm{ka}$ based on our age model) will improve the robustness of the full Onepoto sequence age model.

\subsection{Comparison of the Onepoto and Orakei maar lake sediment sequences}

The well-preserved, mainly rhyolitic, tephra deposits within the $<50 \mathrm{ka}$ segment of the Onepoto palaeolake sequence not only provide an excellent chronological framework for the sequence but also allow for correlation to other long lacustrine records from the AVF (e.g., Orakei Basin and Lake Pupuke; Molloy et al., 2009). While Lake Pupuke's 


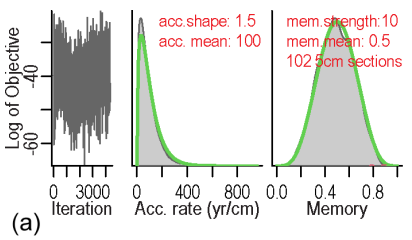

(a)

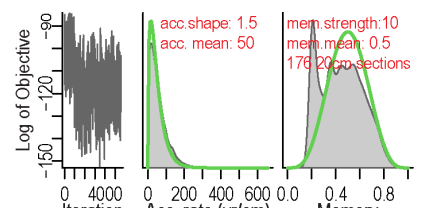

(b)
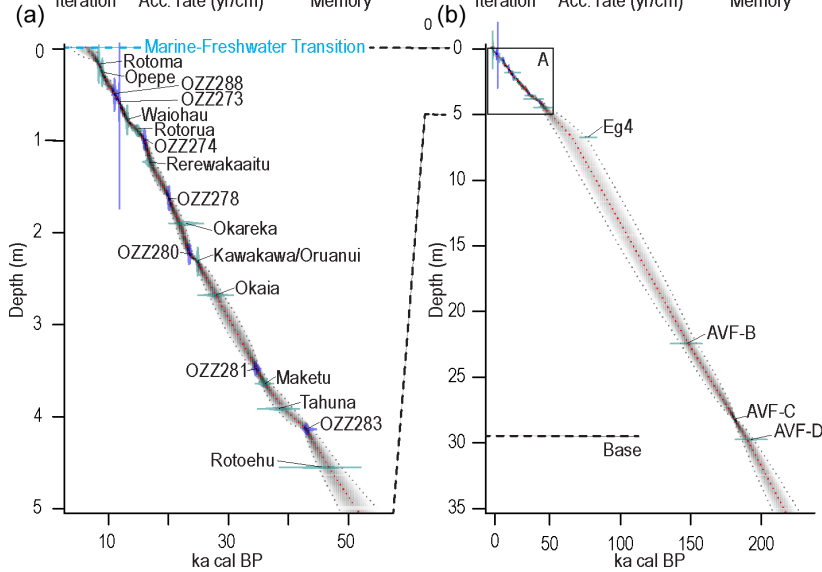

Figure 7. Onepoto lake sediment sequence age model spanning the entire sediment sequence using an event-corrected depth scale established using Rbacon (version 2.5.1; Blaauw and Christen, 2011) in $\mathrm{R}$ (version 1.3.1103; R Core Team, 2020). (a) Post-50 ka record based on AMS ${ }^{14} \mathrm{C}$ ages and known-age rhyolitic tephra ages (mean $95 \%$ confidence ranges $2.03 \mathrm{ka}$, min $0.31 \mathrm{ka}$ at $0.59 \mathrm{~m}$, max $6.11 \mathrm{ka}$ at $50 \mathrm{~m}$ ). (b) Full lake sediment sequence including andesitic tephra and basaltic ejecta as age markers in the pre-50 ka part of the record (mean $95 \%$ confidence ranges $13.23 \mathrm{ka}$, min $0.11 \mathrm{ka}$ at $0.18 \mathrm{~m}$, max $20.85 \mathrm{ka}$ at $10.81 \mathrm{~m}$. The accumulation rate is estimated by Rbacon by millions of Markov Chain Monte Carlo (MCMC) iterations. The memory defines how much the accumulation rate of a particular depth in a core depends on the depth above it (Blaauw and Christen, 2011).

lacustrine sediment sequence has been studied in great detail for the last $50 \mathrm{kyr}$ (e.g., Nilsson et al., 2011; Stephens et al., 2012a, b), a comparison with the palaeolake sediment sequence extracted from nearby Orakei maar (Peti and Augustinus, 2019), however, allows for a correlation of lithostratigraphic units from Onepoto Basin with the highresolution (averaged SAR (sediment accumulation rate) of $0.04 \mathrm{~mm} / \mathrm{yr}$; Peti et al., 2020) terrestrial record from Orakei Basin which spans the last $130 \mathrm{kyr}$. For the period from 50$9 \mathrm{ka}$, the correlation of the two records is guided by the presence of well-visible and geochemically distinct rhyolitic tephra beds (Rotorua, Okareka, Kawakawa/Oruanui, Okaia, Maketu, Tahuna, and Rotoehu) and one basaltic tephra deposit (AVF 12). In contrast, for the period from $130-50 \mathrm{ka}$ our correlation is based upon the presence of the andesitic Eg4 tephra in both records and sedimentary characteristics (colour, texture, evidence of influx organic macro material content, and coarse-grained material).

Both maar lakes were subject to the same regional environmental and climatic drivers determining sediment influx and depositional conditions. Units from the two lake records have been grouped by us to "lithostratigraphic groups" (further referred to as LG) and evaluated as to whether the onset and termination of these units coincide. The correlation of the transitions from one unit to the next relies on a recently established robust age model for Orakei Basin (Peti et al., 2020) and for Onepoto Basin on the age model presented in this study. Correlation of the lithostratigraphic units between the cores is given in Fig. 8.

For LG-1, the lithostratigraphic units at the very top, Unit I(a) (Onepoto) and Unit 1 to Unit 2 (Orakei) show distinct differences with respect to sediment colour, texture, and composition. In both cases their termination is marked by a transition from lacustrine to marine conditions at ca. $9 \mathrm{ka}$. Unit $\mathrm{I}(\mathrm{a})$ is mainly dominated by dark brown to black silts with well-developed laminations (sub-millimetre) and lighter-coloured bands (centimetre scale). Unit 1 and Unit 2 in the Orakei record, on the other hand, are characterised by a transition from light brown massive clay with bioturbation (Unit 2) to peat (Unit 1). This suggests locally varying environmental conditions for the two sites. Onepoto maar lake remained a deep, stratified lake with conditions favouring the development of laminations due to bottom-water/sediment anoxia but with an increased input of fine organic matter until the conclusion of lacustrine conditions (dark colour). On the other hand, Orakei maar lake gradually shallowed over time due to sediment influx, and input of fine organic detritus was reduced. Direct correlation between these units is supported by the presence of Rotorua tephra at ca. $15.64 \mathrm{ka}$ cal BP.

For LG-2, the closest similarities between units of the records are found between Unit I(b) (Onepoto) and units 3 to 7 (Orakei). Both groups share close estimated times of onset (ca. $28 \mathrm{ka}$ ) and termination (ca. $18 \mathrm{ka}$ ) and are similar in sediment colour and composition. The units in both records are dominated by lighter-coloured sediments with moderately well-developed laminations in both. However, the laminae in the Orakei lacustrine sequence are better defined. These sedimentary characteristics suggest a more stratified water column for Orakei maar lake with bottom-water/sediment anoxia before transitioning into banded sands/silts with wood fragments. The latter indicates a gradual shallowing at this site. Input of fine organic matter is somewhat reduced at Onepoto palaeolake and significantly reduced at Orakei palaeolake. Okareka and Kawakawa/Oruanui (KOT) tephra provide reliable age markers at ca. 22.21 and ca. $25.36 \mathrm{kacal}$ BP, respectively, that can be correlated across the two records. In addition, in both records an increase in basaltic tephra deposits is noticeable such as AVF 10 and AVF 12. Not only does this reflect heightened volcanic activity within in the AVF at the time but also indicates that both basins were located downwind from the eruptive cones that produced these tephra.

For LG-3, Unit I(c) (Onepoto) and Unit 8 (Orakei) are both constrained by estimated times of onset of ca. $58 \mathrm{ka}$ and termination of ca. $28 \mathrm{ka}$, respectively. Both lithostrati- 


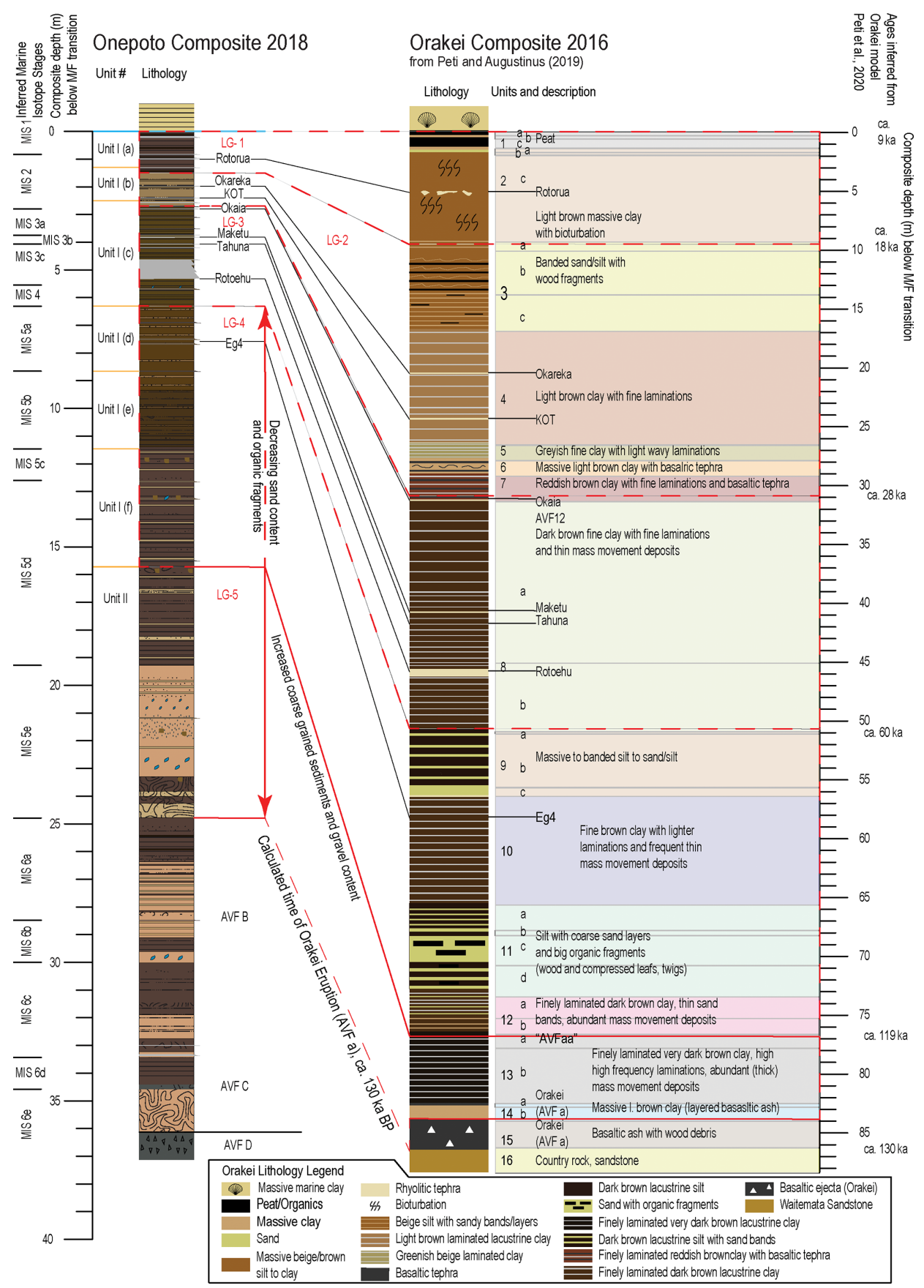

Figure 8. Comparison of lithostratigraphic units identified in the Onepoto and Orakei maar lake records as well as inferred correlations to the MIS 6e-MIS 1 (where MIS represents marine isotope stage). Orakei Basin lake sediment facies model modified from Peti and Augustinus (2019). Lithology legend for Onepoto follows that in Fig. 3. Red dashed lines show corresponding facies transitions; black dashed lines show possibly correlatable tephra beds; red solid lines show transition from sediments with less sandy/coarse content to sediments with increased coarse-grained content; black solid lines show correlatable tephra beds; and the dashed blue line represents the marine-freshwater transition.

graphic units show dark brown, fine-grained sediments with well-developed laminations. While thin, mass-movement deposits are reported for Unit 8, similar features are not found in Unit $\mathrm{I}(\mathrm{c})$, with minor traces of macroscopic plant fragments present in the latter. The observed features indicate mostly comparable environmental conditions for both lakes with water column stratification and bottom-water/sediment anoxia, which allows for the development of well-developed laminations. The dark colouration of the sediments indicates a steady input of fine organic matter into both 
lakes. In this case Okaia (ca. $28.62 \mathrm{ka} \mathrm{cal} \mathrm{BP),} \mathrm{Maketu} \mathrm{(ca.}$ $35.61 \mathrm{ka} \mathrm{cal} \mathrm{BP})$, Tahuna (ca. $37.85 \mathrm{ka} \mathrm{cal} \mathrm{BP}$ ), and Rotoehu (ca. $45.1 \mathrm{ka})$ tephra offer age dates and are reliable marker layers for a direct correlation between these units.

For LG-4 (between ca. 60 to $119 \mathrm{ka}$ ), Onepoto Basin's units $I(d)$ to $I(f)$ share similar characteristics to units 9 to 12 (Orakei). Drawing from the more robust Orakei age model, the onset and termination times can be inferred (ca. 58 and ca. $110 \mathrm{ka})$. The sedimentary characteristics of the individual units from both records share a general trend of a downcore transition from banded (at the top) to increasingly welllaminated sediments. It is important to note though that the distinctness of the preserved laminations in the Orakei record are superior to those of the Onepoto lake sediment record. Similarly, there is a gradual downcore increase in organic detritus and mass-wasting deposits observable in both sequences. Mass-wasting inducing events (e.g., storms and/or earthquakes) and a less fully developed stratification of the water column are at both sites towards the top of this group, indicated by transition from laminations to banding towards the top in Unit I(d) and Unit 9. For this group, Eg4 tephra currently provides the most reliable age marker.

For LG-5 (ca. 130-119 ka), time constraints for this phase are provided by a good agreement between the age model present in this study with the dated age of eruption that formed Orakei Basin (ca. $130 \mathrm{ka}$ ) and the basaltic "AVF aa" tephra recorded in the Orakei lake sediment sequence (ca. $119 \mathrm{ka}$ ). The transition from Unit I to Unit II (Onepoto) and from Unit 12 to Unit 13 (Orakei) is marked by a significant increase in coarse sand and gravel-rich layers with often angular-shaped grains (mass-wasting deposits) in both records. However, the Orakei lake sediment sequence depicts well-developed laminations at high frequency that have no corresponding equivalent in the Onepoto lake sequence. In the latter, laminations are rather poorly to, at best, moderately developed. This suggests better developed water column stratification at Orakei maar lake at this time. Both sites reflect reoccurring strong (coarse grained material) masswasting inducing events (e.g., storms and/or earthquakes). After Orakei maar's formative eruption, the initial shallow lake (massive sediments in Unit 14) transitioned into a deep lake basin with conditions favourable for lamination formation in the profundal zone (high-frequency laminations in Unit 13). Onepoto maar lake, on the other hand, depicts a fully developed lake system with at times not optimal bottom-water conditions that allowed for the development of laminations.

Generally, both lake sediment sequences recorded increased activity of tephra source volcanic centres with felsic magma composition (e.g., TVZ) over the last ca. $45 \mathrm{kyr}$ whilst older lake sediments are largely devoid of rhyolitic tephra. For most of the later stages of infill of both lakes $(<60 \mathrm{ka})$, the identified sedimentary features broadly reflect environmental settings. This is especially the case for LG3 and most of LG-2. However, a diverging trend becomes increasingly apparent prior to the onset of estuarine deposition at ca. $9 \mathrm{ka}$ (later stage of LG-2 and LG-1), displayed by a shallowing upwards trend recorded in the Orakei maar palaeolake. Onepoto maar, on the other hand, remains a deep lake basin until the breach of the crater rim and subsequent onset of estuarine sedimentation. Furthermore, in both maar lake sequences a general trend to increased presence of massmovement deposits (sand to gravel) and organic fragments (e.g., wood) is recorded downcore, especially from the onset of LG-4 onwards ( $>60 \mathrm{ka}$ ) to LG-5. Overall, laminations $(<$ millimetre scale) are more well developed and continuous in the Orakei lake sequence in contrast to the Onepoto lake sediment record (Figs. 3 and 8).

\subsection{Preliminary reconstruction of Onepoto maar lake sediment sequence evolution}

Formation of the crater (> 150-193 ka; AVF D) to AVF C (ca. $181 \mathrm{ka}$ ). This early phase of lake sedimentation can be allocated to MIS 6e based on the available age constraints. However, the disturbed condition of the sediments, likely caused when the drill core penetrated the comparably thick and dense basaltic lapilli of deposit AVF C, does not allow for reliable interpretation of environmental conditions.

AVF C (ca. $181 \mathrm{ka}$ ) to AVF B (ca. $146 \mathrm{ka}$ ). The ca. $35 \mathrm{kyr}$ phase represented in this part of the record can be roughly correlated to MIS 6d, MIS 6c, and MIS 6b (Railsback et al., 2015) based on the given age constraints provided by the age-depth model presented in this study. Overall, the sediments of this section consist of light brown to dark brown silts and clays with mainly poorly to moderately developed laminations and occasional thicker (decimetre-scale) masswasting deposits. We calculate an averaged accumulation of $\sim 1.92 \mathrm{~m}$ clastic and tephra material in this $\sim 6.24 \mathrm{~m}$ part of the record. The transitions from one stage to the next are often marked by changes in colour and facies. While the ca. $1 \mathrm{~m}$ thick dark brown silts with moderately to well-developed laminations above AVF $\mathrm{C}$ align with MIS 6d, the following $2 \mathrm{~m}$ of sediments above can be correlated to MIS $6 \mathrm{c}$. The preservation of laminated sediments during MIS $6 \mathrm{~d}$ infer the presence of a stratified water column with bottom-water conditions or sediment anoxia that prevented sediment bioturbation. In contrast, the sediments of MIS $6 \mathrm{~d}$ contain a thicker dark brown mass-wasting deposit and light brown silts with poor to moderately developed laminations. The latter depicts less favourable bottom-water conditions for the development of laminated sediments. MIS $6 \mathrm{~b}$ is represented by $\sim 2 \mathrm{~m}$ of massive light brown clayey silts with vivianite flecks and dark brown silts with moderately developed laminations that suggest another phase of suboptimal bottom-water condition for lamination development.

$A V F B$ (ca. $146 \mathrm{ka}$ ) to Eg4 (77.17 ka). Between the Eg4 (ca. $77 \mathrm{ka}$ ) and AVF B tephra (ca. $146 \mathrm{ka}$ ), a ca. $69 \mathrm{kyr}$ duration of lacustrine sedimentation is generally marked by repeated influx of crater-wall-sourced sands and gravel as well as metre- 
scale subaqueous debris flow deposits. Altogether, we document an averaged accumulation of $\sim 4.94 \mathrm{~m}$ of clastic and tephra material for this $\sim 7.56 \mathrm{~m}$ part of the record. Here changes in colour and facies or transitions from one lithological unit to the other do not always strictly trace shifts between marine isotope stages. This either implies local environmental drivers partially overriding broader climatic trends or that climatic changes occurring recorded elsewhere have not set in the same time in the area around at the study site. While the $\sim 2 \mathrm{~m}$ of sediments following AVF B consists of mainly light brown clayey silts with gritty bands, a noticeable transition occurs at $26.46 \mathrm{~m}$ with the onset of $\sim 0.75 \mathrm{~m}$ dark brown silts with well-developed laminations and comparably reduced influx of crater-rim-sourced material reflecting a brief phase of stable environmental conditions and bottom-water/sediment anoxia due to a stratified water column. From our age model, an estimated age of ca. $130 \mathrm{ka}$ is inferred. The phase from the AVF B event to the deposition of the thick mass-wasting deposit can therefore be allocated to MIS 6a, placing it in the Penultimate Glacial Maximum (PGM). We interpret the cause of the subaqueous debris flow deposit to be possibly related to a significant seismic shock that was perhaps triggered by the formative eruption of Orakei Basin calculated to ca. $130 \mathrm{ka}$ (Peti et al., 2021; see correlation Fig. 8). A slightly younger deposit of light brown clayey silts rich in abundant basaltic detritus (at 21-22 m; estimated age 126-127 ka) may be the product of an increased local volcanic activity such as the Orakei crater in a very early stage of its existence. Additionally, during this time (MIS 5e) the Onepoto maar ring is a substantial feature well protected from high MIS 5e sea levels by the tuff ring. A renewed shift in sediment colour and facies occurs at $19.36 \mathrm{~m}$ with the onset of dark brown $\sim 1.6 \mathrm{~m}$ thick silts with well-developed laminations exhibiting a renewed phase of stable environmental conditions with a stratified water column and anoxic bottom waters or sediments. We can assign an estimated age range from 124-122 ka for this stage of Onepoto maar lake's evolution and correlate this phase with the onset of MIS 5d. Furthermore, the transition from lithostratigraphic Unit II to (Sub-)Unit I(f) at $15.8 \mathrm{~m}$ can be inferred to have occurred during MIS 5d at ca. $119 \mathrm{ka}$. The latter is supported by the existence of AVF aa (age in the Orakei maar lake record (Fig. 8)). Moreover, the current age constraints suggest the transition from MIS $5 \mathrm{~d}$ to $5 \mathrm{c}$ to be recorded at $12.6 \mathrm{~m}$ as well as the transition from MIS $5 \mathrm{c}$ to $5 \mathrm{~b}$ at $11.46 \mathrm{~m}$, which coincides with the transition from SubUnit I(f) to Sub-Unit I(e). Additionally, the MIS 5b to MIS 5a boundary can be placed at the contact of Sub-Unit I(e) to Sub-Unit I(d) at $8.65 \mathrm{~m}$. Unlike Orakei Basin where the individual substages of MIS 5 thus far could not be reliably detected by the recently executed study for this site (Peti, 2020), the $>130$ ka part of the Onepoto lake sediment record seems to reflect changes in lithological composition in response to broader climatic shifts. Yet, a further strengthening of the age model will be required for a robust interpretation.
Eg4 tephra to M/F (ca. 77-9 ka; upper $\sim 7.56 \mathrm{~m}$ of the record). The lithostratigraphic sub-units $\mathrm{I}(\mathrm{a})$ to $\mathrm{I}(\mathrm{d})$ span the phase after the deposition of the Eg4 tephra until the transition to estuarine conditions. Overall, an average thickness of $\sim 0.87 \mathrm{~m}$ of clastic material and tephra was deposited in the basin during this phase (Fig. 3) and may infer relatively stable environmental conditions with few sediment influx events. For this late phase of the Onepoto development, robust age constraints are provided by rhyolitic tephra ages and radiocarbon ages (Fig. 7). Well-laminated sediments are mainly found in Sub-Unit I(c), which we can correlate with MIS 3a. The available age constraints demonstrate that the largest part of this unit relates to the phase prior to the Last Glacial Maximum (LGM). However, the presence of Okaia tephra ca. $28.62 \mathrm{ka} \mathrm{cal} \mathrm{BP}$ also highlights that the uppermost section could contain signals that support the eLGM (extended LGM; Newnham et al., 2007) of New Zealand (Rother et al., 2014). Further, Sub-Unit I(a) that follows above can be assigned to the late MIS 2 to MIS 1 transition. The preservation of these laminations indicates renewed phases of water column stratification with bottom-water/sediment anoxia preventing sediment bioturbation. Sub-Unit I(b) can therefore confidently be correlated to the LGM. A detailed description and interpretations on the regional environmental evolution recorded in the ca. 30-9 ka section of the lake sediment sequence are outlined in $\mathrm{Au}-$ gustinus et al. $(2011,2012)$ based on the analysis of pollen and diatom assemblages as well as geochemical proxies.

\section{Possible project outcomes}

A multi-method, high-resolution chronology (centennial to decadal timescale) is currently being established for the Onepoto palaeolake sediment sequence. This process uses radiocarbon dating, and U/Th dating on a large $(4 \times 1 \mathrm{~cm})$ vivianite nodule (sub-unit I(f), ca. $13.35 \mathrm{~m}$ below M/F transition), relative palaeo-intensity variation of the Earth's magnetic field for targeted areas of the sediment record and magnetic-field-strength-controlled influx of meteoric ${ }^{10} \mathrm{Be}$ cosmogenic radionuclides into the basin. This approach mirrors aspects of the approach used for the Orakei palaeolake age model development (Peti et al., 2020) and will assist with development of robust high-resolution correlations between the lengths of the two sequences in common. The approach of combined palaeo-intensity variation and meteoric ${ }^{10} \mathrm{Be}$ has also been recently applied to the Lake Selina (Tasmania, Australia) sediment sequence and aided the chronology development (Lisé-Pronovost et al., 2021), which supports our expectations of this technique. Alongside this work, a comparison and correlation of the Orakei basin record and its recently established robust age model (Peti et al., 2020) with the newly established maar lake record presented here shows the potential of transferring key aspects of the Orakei age model to the Onepoto lake sediment sequence age model. 
We expect the available multi-element $\mu$-XRF core scanning time series to be crucial in linking the two records more robustly together. Furthermore, we are combining these $\mu$-XRF downcore variability trends with measurements of loss-on-ignition, carbon and nitrogen content, and carbon isotopes to start the process of reconstructing climatically forced environmental change from northern New Zealand over much of the last two glacial cycles (ca. $200 \mathrm{ka}$ ). Representative thin-sections are also being examined from parts of the record with well-developed laminations $(<$ millimetre scale) for micro-facies analysis to detect abrupt climate shifts and short- to long-term changes in seasonality. Extending pollen and diatom analyses prior to MIS 3 (Augustinus et al., 2011, 2012) will also provide important palaeoecological information necessary for development of detailed insights into drivers of changes in Onepoto palaeolimnology as well as catchment palaeoecology and associated palaeoclimate.

Multi-proxy analysis of the Onepoto maar lake sediments is expected to produce the following insights:

1. Further development of improved constraints for the frequency and magnitude of regional basaltic volcanic activity within the Auckland Volcanic Field by delivering better age estimates, especially prior to the deposition of the known-age Rotoehu tephra by combining the recently refined ages presented in Peti et al. (2021) with new results produced from the new Onepoto record.

2. A refined tephrochronology for Onepoto from all volcanic sources will also allow for an improved volcanic hazard assessment for Auckland City. As well as AVF basaltic volcanism, ash falls from distal sources (mostly andesitic but also rhyolitic) are a frequently reoccurring volcanic hazard for the Auckland region.

3. The dating of tephra age markers older than $50 \mathrm{ka}$ using meteoric cosmogenic nuclide $\left({ }^{10} \mathrm{Be}\right)$ variability in the Onepoto sediments driven by well-known changes in Earth's magnetic field intensity (see references in Peti et al., 2020) will enable more accurate and precise dating of the sequence. Our study aims to achieve an overlap with the Orakei maar record below the Rotoehu tephra (45 ka and the Laschamp excursion (ca. $41 \mathrm{ka}$, Nilsson et al., 2011) to complement the Orakei age model. This approach will likely establish trends of meteoric cosmogenic nuclide $\left({ }^{10} \mathrm{Be}\right)$ variability spanning nearly two full glacial cycles. We expect that the Onepoto age model will be robust enough to be able to observe environmental oscillations and events identified in the sequence to regional and possibly intra- and inter-hemispheric climatic events.

4. Principal component analysis (PCA) of the $\mu$-XRF core scanning time series will provide additionally aid for our palaeoenvironmental interpretation. Application of this approach to high-resolution XRF data identifies the processes and features that drive the observed variability.

\section{Conclusions}

The ongoing study of the lake sediment sequence contained in Onepoto maar outlined here has produced a composite facies log derived from overlapping core sections guided by prominent tephra layers and sedimentary features such as mass movement deposits, distinct well-laminated segments and features representative of distinctive facies types. More challenging core section alignments were achieved using high-resolution radiographic images, tephrochronology, $\mu$ XRF and magnetic susceptibility time series data.

The preliminary Onepoto age model presented here reflects the issue of poor age control for large sections of the pre-50 ka sequence. Nevertheless, promising improvements have been made by correlating the Onepoto sequence to that of Orakei Basin, thereby extending age control to the base of that sequence using a range of known-age tie points. Age markers for the early stage of the lake and its eruptive formation are provided through AVF-sourced basaltic ejecta (AVF B/ AVF C) and the lava at the base (AVF D). Significant age uncertainties, especially for AVF D, or independently supported ages as in the case of AVF $\mathrm{C}$ and the lack of further reliable marker layers (e.g., AVF A) between Eg4 to AVF B (spanning ca. 69 ka) as well as AVF B to AVF C (spanning ca. $34 \mathrm{ka}$ ) require more robust age constraints. This is currently underway using ${ }^{10} \mathrm{Be}$ cosmogenic nuclide flux supported by measurement of relative magnetic palaeo-intensity variation in sections of the core (e.g., Laschamp Event) using an approach analogous to that used for the Orakei maar lake chronology development.

The pre-77 ka phase of lake sediment deposition at Onepoto is marked by a dominance of debris flows and deposition of many thin andesitic tephra (mainly sub-millimetrescale thickness) originating from distal volcanic centres (e.g., Egmont/Taranaki and Tongariro VCs). However, discontinuous sections of well-developed laminations $(<$ millimetre scale) are also present. These findings are indicative of phases of varying clastic input/chemical conditions driven by climatic signals while the preservation was affected by bottom-water/sediment anoxia driven by water column stratification preventing sediment bioturbation.

AVF maar lake sediments exhibit enormous potential for the identification and interpretation of short-duration climate events and long-term climate trends as well as intra- and inter-hemispheric climate. In tandem with ongoing work on Orakei maar, the study of Onepoto maar lake sediments will extend this record by providing high-resolution palaeoclimate and palaeoenvironmental reconstructions spanning the last two glacial cycles. 
Data availability. AMS ${ }^{14} \mathrm{C}$ data are presented in the text and the results of the geochemical tephra analysis are provided in Table S2 of the Supplement. Furthermore, the data are accessible on the following online repositories: https://doi.org/10.6084/m9.figshare.13683874 (Läuchli and Augustinus, 2021) and https://doi.org/10.6084/m9.figshare.13683658 (Läuchli et al., 2021). The DOI links are also included in the captions of the tables. Additional data are currently not yet publicly available in this progress report as they are still undergoing evaluation. All data will be made available upon completion of the ongoing work, when scientific papers are published.

Supplement. The supplement related to this article is available online at: https://doi.org/10.5194/sd-29-19-2021-supplement.

Author contributions. PCA leads the AVF maar project, secured funding, and is involved in all aspects of the work. BL conducted the core descriptions, Itrax $\mu$-XRF core scans, and development of the composite stratigraphy. EMPA measurements of tephra samples were conducted by JLH at Victoria University of Wellington. BL wrote the original version of this report with refinements from PCA with suggestions provided by LP and JLH. The drilling investigation team included PCA, BL, and LP.

Competing interests. The authors declare that they have no conflict of interest.

Acknowledgements. Funding for the project was provided by DeVORA (funded by New Zealand's Earthquake Commission and the Auckland Council) as well as a grant from the Royal Society of New Zealand's Marsden Fund (014-UOA-140 to Paul Augustinus). Benjamin Läuchli thanks Daniela Cerda for tephra sampling/analyses, magnetic susceptibility sampling, and Itrax core scanning support. AMS radiocarbon analyses (including preparatory lab work) were executed at the ANSTO (Australian Nuclear Science and Technology Organisation), Sydney, Australia. Benjamin Läuchli thanks AINSE Limited for providing financial assistance (Award - PGRA 12446) to enable work at the ANSTO Centre for Accelerator Science (radiocarbon dating). We thank two anonymous reviewers for the detailed comments that have significantly improved this paper as well as Thomas Wiersberg for his editorial work.

Financial support. This research has been supported by DeVORA (funded by New Zealand's Earthquake Commission and the Auckland Council), a grant from the Royal Society of New Zealand's Marsden Fund (grant no. 014-UOA-140), and AINSE Limited (Award - PGRA 12446).

Review statement. This paper was edited by Thomas Wiersberg and reviewed by two anonymous referees.

\section{References}

Alloway, B. V., Lowe, D. J., Barrell, D. J. A., Newnham, R. M., Almond, P. C., Augustinus, P. C., Bertler, N. A. N., Carter, L., Litchfield, N. J., McGlone, M. S., Shulmeister, J., Vandergoes, M. J., and Williams, P. W.: Towards a climate event stratigraphy for New Zealand over the past 30000 years (NZ-INTIMATE project), J. Quaternary Sci., 22, 9-35, https://doi.org/10.1002/Jqs.1079, 2007.

Augustinus, P. C., D’Costa, D., Deng, Y., Hagg, J., and Shane, P.: A multi-proxy record of changing environments from ca. 30000 to 9000 cal. a BP: Onepoto maar paleolake, Auckland, New Zealand, J. Quaternary Sci., 26, 389-401, https://doi.org/10.1002/jqs.1463, 2011.

Augustinus, P. C., Cochran, U., Kattel, G., D'Costa, D., and Shane, P.: Late Quaternary paleolimnology of Onepoto maar, Auckland, New Zealand: Implications for the drivers of regional paleoclimate, Quaternary. Int., 253, 18-31, https://doi.org/10.1016/j.quaint.2011.02.028, 2012.

Blaauw, M. and Christen, J. A.: Flexible paleoclimate agedepth models using an autoregressive gamma process, Bayesian Anal., 6, 457-474, https://doi.org/10.1214/11-BA618, 2011.

Brauer, A., Endres, C., and Negendank, J. F.: Lateglacial calendar year chronology based on annually laminated sediments from Lake Meerfelder Maar, Germany, Quaternary Int., 61, 17-25, https://doi.org/10.1016/S1040-6182(99)00014-2, 1999.

Bronk Ramsey, C.: Bayesian analysis of radiocarbon dates, Radiocarbon, 511, 337-360, https://doi.org/10.1017/S0033822200033865, 2009.

Croudace, I. W. and Rothwell, R. G.: Micro-XRF sediment core scanners: important new tools for the environmental and earth sciences, Spectroscopy Europe, 22, 6-13, https://doi.org/10.1007/978-94-017-9849-5, 2015.

Croudace, I. W., Rindby, A., and Rothwell, R.: ITRAX: description and evaluation of a new multi-function X-ray core scanner, Geol. SOC. Spec. Publ., London, 267, 51 LP-63, https://doi.org/10.1144/GSL.SP.2006.267.01.04, 2006.

Danišík, M., Shane, P., Schmitt, A. K., Hogg, A., Santos, G. M., Storm, S., Evans, N. J., Fifield, L. K., and Lindsay, J. M.: Re-anchoring the late Pleistocene tephrochronology of New Zealand based on concordant radiocarbon ages and combined $238 \mathrm{U} / 230^{\mathrm{Th}}$ disequilibrium and (UTh)/He zircon ages, Earth. Planet. Sci. Lett., 349, 240-250, https://doi.org/10.1016/j.epsl.2012.06.041, 2012.

Danišík, M., Lowe, D. J., Schmitt, A. K., Friedrichs, B., Hogg, A. G., and Evans, N. J.: Sub-millennial eruptive recurrence in the silicic Mangaone Subgroup tephra sequence, New Zealand, from Bayesian modelling of zircon doubledating and radiocarbon ages, Quat. Sci. Rev., 246, 106517, https://doi.org/10.1016/j.quascirev.2020.106517, 2020.

Fink, D., Hotchkis, M., Hua, Q., Jacobsen, G., Smith, A. M., Zoppi, U., Child, D., Mifsud, C., van der Gaast, H., Williams, A., and Williams, M.: The ANTARES AMS facility at ANSTO, NIM B, 223-224, 109-115, 2004.

Francus, P., Lamb, H., Nakagawa, T., Marshall, M., and Brown, E.: The potential of high-resolution X-ray fluorescence core scanning: applications in paleolimnology, PAGES (Past Global Changes) News, 17, 93-95, 2009. 
Hägg, J. and Augustinus, P. C.: Scientific data report from the Onepoto Crater drilling (NZ-Maar) project: December 2000/July 2001, pp. 7-15, 2003.

Hayward, B. W., Morley, M. S., Sabaa, A. T., Grenfell, H. R., Molloy, C., Shane, P. A., and Augustinus, P. A.: Fossil record of the Post-glacial marine breaching of Auckland's volcanic maar craters, Records of the Auckland Museum, 45, 73-99, 2008.

Hogg, A. G., Heaton, T. J., Hua, Q., Palmer, J. G., Turney, C. S., Southon, J., Bayliss, A., Blackwell, P. G., Boswijk, G., Ramsey, C. B., and Pearson, C.: SHCal20 Southern Hemisphere Calibration, 0-55,000 Years cal BP, Radiocarbon, 62, 759-778, https://doi.org/10.1017/RDC.2020.59, 2020.

Hopkins, J. L., Millet, M. A., Timm, C., Wilson, C. J. N., Leonard, G. S., Palin, J. M., and Neil, H.: Tools and techniques for developing tephra stratigraphies in lake cores: A case study from the basaltic Auckland Volcanic Field, New Zealand, Quaternary Sci. Rev., 123, 58-75, https://doi.org/10.1016/j.quascirev.2015.06.014, 2015.

Hopkins, J. L., Wilson, C. J. N., Millet, M. A., Leonard, G. S., Timm, C., McGee, L. E., Smith, I. E. M., and Smith, E. G. C.: Multi-criteria correlation of tephra deposits to source centres applied in the Auckland Volcanic Field, New Zealand, B. Volcanol., 79, 55, https://doi.org/10.1007/s00445-017-1131-y, 2017.

Hopkins, J. L., Smid, E. R., Eccles, J. D., Hayes, J. L., Hayward, B. W., McGee, L. E., van Wijk, K., Wilson, T. M., Cronin, S. J., Leonard, G. S., and Lindsay, J. M.: Auckland Volcanic Field magmatism, volcanism, and hazard: a review, New Zeal. J. Geol. Geop., 1-22, https://doi.org/10.1080/00288306.2020.1736102, 2020.

Jarvis, S., Croudace, I. W., and Rothwell, R. G.: Parameter optimisation for the ITRAX core scanner, in: Micro-XRF Studies of Sediment Cores, Springer, Dordrecht, pp. 535-562, https://doi.org/10.1007/978-94-017-9849-5_22, 2015.

Kylander, M. E., Lind, E. M., Wastegard, S., and Lowemark, L.: Recommendations for using XRF core scanning as a tool in tephrochronology, Holocene, 22, 371-375, https://doi.org/10.1177/0959683611423688, 2012.

Läuchli, B. and Augustinus, P. C.: AMS radiocarbon ages from the Onepoto maar lake sediment record, figshare, https://doi.org/10.6084/m9.figshare.13683874, 2021.

Läuchli, B., Augustinus, P. C., and Hopkins, J. L.: Onepoto2018_Tephra_Rotoma-Eg4, figshare, https://doi.org/10.6084/m9.figshare.13683658, 2021.

Leonard, G. S., Calvert, A. T., Hopkins, J. L., Wilson, C. J. N., Smid, E. R., Lindsay, J. M., and Champion, D. E.: High-precision 40Ar/39Ar dating of Quaternary basalts from Auckland Volcanic Field, New Zealand, with implications for eruption rates and paleomagnetic correlations, J. Volcanol. Geoth. Res., 343, 60-74, https://doi.org/10.1016/j.jvolgeores.2017.05.033, 2017.

Lindsay, J. M., Leonard, G. S., Smid, E. R., and Hayward, B. W.: Age of the Auckland Volcanic Field: a review of existing data, New Zeal. J. Geol. Geop., 54, 379-401, https://doi.org/10.1080/00288306.2011.595805, 2011.

Lisé-Pronovost, A., Fletcher, M. S., Simon, Q., Jacobs, Z., Gadd, P. S., Heslop, D., Herries A. I. R., and Yokoyama, Y.: Chronostratigraphy of a 270-ka sediment record from Lake Selina, Tasmania: Combining radiometric, geomagnetic and climatic dating, Quat. Geochronol., 62, 101152, https://doi.org/10.1016/j.quageo.2021.101152, 2021.
Lowe, D. J., Blaauw, M., Hogg, A. G., and Newnham, R. M.: Ages of 24 widespread tephras erupted since 30,000 years ago in New Zealand, with re-evaluation of the timing and paleoclimatic implications of the Lateglacial cool episode recorded at Kaipo bog, Quaternary Sci. Rev., 74, 170-194, https://doi.org/10.1016/j.quascirev.2012.11.022, 2013.

Löwemark, L., Chen, H. F., Yang, T. N., Kylander, M., Yu, E. F., Hsu, Y. W., Lee, T. Q., Song, S. R., and Jarvis, S.: Normalizing XRF-scanner data: a cautionary note on the interpretation of high-resolution records from organic-rich lakes, J. Asian Earth Sci., 40, 1250-1256, https://doi.org/10.1016/j.jseaes.2010.06.002, 2011.

Marchetto, A., Ariztegui, D., Brauer, A., Lami, A., Mercuri, A. M., Sadori, L., Vigliotti, L., Wulf, S., and Guilizzoni, P.: Volcanic Lake Sediments as Sensitive Archives of Climate and Environmental Change, in: Volcanic Lakes, edited by: Rouwet, D., Christenson, B., Tassi, F., and Vandemeulebrouck, J., Berlin, Heidelberg: Springer Berlin Heidelberg, pp. 379-399, https://doi.org/10.1007/978-3-642-36833-2_17, 2015.

Molloy, C.: Tephrostratigraphy of the Auckland Maar Craters (unpublished master's thesis), University of Auckland, New Zealand, 2008.

Molloy, C., Shane, P., and Augustinus, P. C.: Eruption recurrence rates in a basaltic volcanic field based on tephra layers in maar sediments: Implications for hazards in the Auckland volcanic field, Bull. Geol. Soc. Am., 121, 1666-1677, https://doi.org/10.1130/B26447.1, 2009.

Newnham, R. M., Lowe, D. J., Giles, T., and Alloway, B. V.: Vegetation and climate of Auckland, New Zealand, since ca. 32000 cal. yr ago: support for an extended LGM, J. Quat. Sci., 22, 517-534, 2007.

Nilsson, A., Muscheler, R., Snowball, I., Aldahan, A., Possnert, G., Augustinus, P. C., Atkin, D., and Stephens, T.: Multi-proxy identification of the Laschamp geomagnetic field excursion in Lake Pupuke, New Zealand, Earth Planet. Sci. Lett., 311, 155-164, https://doi.org/10.1016/j.epsl.2011.08.050, 2011.

Nunns, A. G. and Hochstein, M. P.: Geophysical constraints on the structure and formation of Onepoto, Orakei, Pupuke and Tank Farm maar volcanoes, Auckland Volcanic Field, New Zeal. J. Geol. Geop., 62, 341-356, https://doi.org/10.1080/00288306.2019.1581239, 2019.

Peti, L.: High-resolution composite stratigraphy and multi-method dating of Auckland maar sediment records spanning the Last Glacial Interval (unpublished doctoral thesis), University of Auckland, New Zealand, 2020.

Peti, L. and Augustinus, P. C.: Stratigraphy and sedimentology of the Orakei maar lake sediment sequence (Auckland Volcanic Field, New Zealand), Sci. Dril., 25, 47-56, https://doi.org/10.5194/sd-25-47-2019, 2019.

Peti, L., Fitzsimmons, K. E., Hopkins, J. L., Nilsson, A., Fujioka, T., Fink, D., Mifsud, C., Christl, M., Muscheler, R., and Augustinus, P. C.: Development of a multi-method chronology spanning the Last Glacial Interval from Orakei maar lake, Auckland, New Zealand, Geochronology, 2, 367-410, https://doi.org/10.5194/gchron-2-367-2020, 2020.

Peti, L., Hopkins, J. L., and Augustinus, P. C.: Revised tephrochronology for key tephras in the 130-ka Ōrākei Basin maar core, Auckland Volcanic Field, New Zealand: implications 
for the timing of climatic changes, New Zeal. J. Geol. Geophy., 1-15, https://doi.org/10.1080/00288306.2020.1867200, 2021.

Poth, D. and Negendank, J. F.: Paleoclimate reconstruction at the Pleistocene/Holocene transition - A varve dated microstratigraphic record from Lake Meerfelder Maar (Westeifel, Germany), in: Paleolimnology of European maar lakes, Springer, Berlin, Heidelberg, pp. 209-222, https://doi.org/10.1007/BFb0117598, 1993.

Railsback, L. B., Gibbard, P. L., Head, M. J., Voarintsoa, N. R. G., and Toucanne, S.: An optimized scheme of lettered marine isotope substages for the last 1.0 million years, and the climatostratigraphic nature of isotope stages and substages, Quaternary Sci. Rev., 111, 94-106, https://doi.org/10.1016/j.quascirev.2015.01.012, 2015.

$\mathrm{R}$ Core Team: A language and environment for statistical computing, R Foundation for Statistical Computing, Vienna, Austria, available at: https://www.R-project.org/ (last access: 1 February 2021), 2020.

Rother, H., Fink, D., Shulmeister, J., Mifsud, C., Evans, M., and Pugh, J.: The early rise and late demise of New Zealand's last glacial maximum, P. Natl. Acad. Sci. USA, 11, 11630-11635, https://doi.org/10.1073/pnas.1401547111, 2014.

Sandiford, A., Newnham, R., Alloway, B., and Ogden, J.: A 28 000$7600 \mathrm{cal}$ yr BP pollen record of vegetation and climate change from Pukaki Crater, northern New Zealand, Paleogeogr. Paleoclimatol. Paleoecol., 201, 235-247, https://doi.org/10.1016/S00310182(03)00611-4, 2003.

Shane, P. and Hoverd, J.: Distal record of multi-sourced tephra in Onepoto Basin, Auckland, New Zealand: implications for volcanic chronology, frequency and hazards, B. Volcanol., 64, 441454, https://doi.org/10.1007/s00445-002-0217-2, 2002.

Shane, P. and Sandiford, A.: Paleovegetation of marine isotope stages 4 and 3 in Northern New Zealand and the age of the widespread Rotoehu tephra, Quaternary Res., 59, 420-429, https://doi.org/10.1016/S0033-5894(03)00044-9, 2003.

Sirocko, F., Knapp, H., Dreher, F., Förster, M. W., Albert, J., Brunck, H., Veres, D., Dietrich, S., Zech, M., Hambach, U., Röhner, M., Rudert, S., Schwibus, K., Adams, C., and Sigl, P.: The ELSA-Vegetation-Stack: Reconstruction of Landscape Evolution Zones (LEZ) from laminated Eifel maar sediments of the last 60000 years, Glob. Planet. Change, 142, 108-135, 2016.
Stephens, T., Atkin, D., Augustinus, P. C., Shane, P., Lorrey, A., Street-Perrott, A., Nilsson, A., and Snowball, I.: A late glacial Antarctic climate teleconnection and variable Holocene seasonality at Lake Pupuke, Auckland, New Zealand, J. Paleolimnol., 48, 785-800, 2012a.

Stephens, T., Atkin, D., Cochran, U., Augustinus, P. C., Reid, M., Lorrey, A., Shane, P., and Street-Perrott, A.: A diatominferred record of reduced effective precipitation during the Last Glacial Coldest Phase (28.8-18.0 cal kyr BP) and increasing Holocene seasonality at Lake Pupuke, Auckland, New Zealand, J. Paleolimnol., 48, 801-817, https://doi.org/10.1007/s10933012-9645-y, 2012b.

St.-Onge, G., Mulder, T., Francus, P., and Long, B.: Chapter Two Continuous Physical Properties of Cored Marine Sediments, in: Proxies in Late Cenozoic Paleoceanography, edited by: Hillaire-Marcel, C., and De Vernal, A. B. T., Elsevier, 1, 6398, https://doi.org/10.1016/S1572-5480(07)01007-X, 2007.

Vandergoes, M. J., Hogg, A. G., Lowe, D. J., Newnham, R. M., Denton, G. H., Southon, J. B., David, J. A., Wilson, C. J. N., McGlone, M. S., Allan, A. S. R., Almond, P. C., Petchey, F., Dabell, K., Dieffenbacher-Krall, A. C., and Blaauw, M.: A revised age for the Kawakawa/Oruanui tephra, a key marker for the Last Glacial Maximum in New Zealand, Quat. Sci. Rev., 74, 195-201, https://doi.org/10.1016/j.quascirev.2012.11.006, 2013.

Williams, T., Creer, K. M., and Thouveny, N.: Preliminary $50 \mathrm{~m}$ paleomagnetic records from Lac Du Bouchet, Haute Loire, France", in: Paleolimnology of European Maar Lakes, edited by: Negendank, J. F. W. and Zolitschka, B., Lecture Notes in Earth Sciences, Springer, Berlin, Heidelberg, 49, 367-376, https://doi.org/10.1007/BFb0117607, 1993.

Zolitschka, B. and Enters, D.: Lacustrine sediments,, in: Encyclopedia of Paleoclimatology and Ancient Environments, edited by: Gornitz, V., Encyclopedia of Earth Sciences Series, Springer, Dordrecht, the Netherlands, 486-488, https://doi.org/10.1007/978-1-4020-4411-3_120 2009.

Zolitschka, B., Anselmetti, F., Ariztegui, D., Corbella, H., Francus, P., Lücke, A., Maidana, N. I., Ohlendorf, C., Schäbitz, F., and Wastegård, S.: Environment and climate of the last 51,000 years-new insights from the Potrok Aike maar lake Sediment Archive Drilling project (PASADO), Quaternary Sci. Rev., 71, 1-12, https://doi.org/10.1016/j.quascirev.2012.11.024, 2013. 